IRSH 50 (2005), pp. 203-240 DOI: I0.1017/S0020859005001938

(C) 2005 Internationaal Instituut voor Sociale Geschiedenis

\title{
The British and French Representatives to the Communist International, I920-I939: A Comparative Survey*
}

\author{
John MCILROy AND Alan CAMPBELL
}

Summary: This article employs a prosopographical approach in examining the backgrounds and careers of those cadres who represented the Communist Party of Great Britain and the Parti Communiste Français at the Comintern headquarters in Moscow. In the context of the differences between the two parties, it discusses the factors which qualified activists for appointment, how they handled their role, and whether their service in Moscow was an element in future advancement. It traces the bureaucratization of the function, and challenges the view that these representatives could exert significant influence on Comintern policy. Within this boundary the fact that the French representatives exercised greater independence lends support, in the context of centre-periphery debates, to the judgement that within the Comintern the CPGB was a relatively conformist party.

Neither the literature on the Communist International (Comintern) nor its national sections has a great deal to say about the permanent representatives of the national parties in Moscow. The opening of the

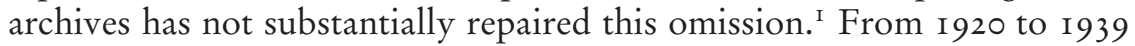
fifteen British communists acted as their party's representatives to the

\footnotetext{
* This article started life as a paper delivered to the Fifth European Social Science History Conference, Berlin, 24-27 March 2004. Thanks to Richard Croucher, Barry McLoughlin, Emmet O'Connor, Bryan Palmer, Reiner Tosstorff, and all who participated in the "Russian connections" session.

I. The only brief account remains Branko Lazitch, "Two Instruments of Control by the Comintern: The Emissaries of the ECCI and the Party Representatives in Moscow", in Milorad M. Drachkovitch and Branko Lazitch (eds), The Comintern: Historical Highlights (Stanford, CA, I966), pp. 54-64. For brief comments on the representatives after the opening of the archives, see Brigitte Studer, "More Autonomy for the National Sections? The Reorganization of the ECCI after the Seventh World Congress", in Mikhail Narinsky and Jürgen Rojahn (eds), Centre and Periphery: The History of the Comintern in the Light of New Documents (Amsterdam, 1996), pp. 102-II3, 108; Brigitte Studer, Un parti sous influence: Le Parti communiste suisse, une section du Komintern, I93 I à I939 (Lausanne, I994), pp. 257-262; Serge Wolikow, "L'Internationale communiste 1919-1943", in José Gotovitch and Mikhail Narinski (eds) Komintern: L'bistoire et les hommes (Paris, 200I), pp. I 5-92, 84-85.
} 
Comintern. While they are referred to, and their comings and goings chronicled, recent published work omits any considered assessment of their role. ${ }^{2}$

Following on suggestions for further research made by Brigitte Studer and Serge Wolikow, this paper provides biographical information on the most important group of British communists resident in Moscow. ${ }^{3}$ It discusses their functions and measures their activities against images of these cadres as ambassadors, consuls, or delegates from the Communist Party of Great Britain (CPGB). ${ }^{4}$ It addresses the question of whether they exercised power and negotiated decisions. Or whether they were subordinate emissaries, even civil servants, who acted as the instruments of bureaucratic power-holders. In the context of claims that the relationship between London and Moscow was one of "negotiation", this article explores the view that "the British representative could play a significant role"s in influencing Comintern policy, depending on his standing with the bureaucracy. It scrutinizes the origins, career progression, and political destinations of the representatives before turning to similar examination of the background and role of those who represented the Parti Communiste Français (PCF) in Moscow. In broad prosopographical terms, the article draws distinctions and observes parallels between the British cadres and their French counterparts.

Unlike the CPGB, the PCF stemmed from a substantial split in the labour movement and sank deeper roots in the working class. Marxism was stronger in France, and the PCF, inheriting a more powerful and recent revolutionary tradition, did not have to confront a hegemonic, corporatist, reformist formation in the shape of the British Labour Party. Thus, with political space available, it developed into a mass party with real influence in national politics and civil society. By 1938 its parliamentary presence, its 3 I 8,000 members, its influence on the state, and its social reach dwarfed the CPGB's i6,000 members and a solitary Member of Parliament. The PCF possessed a richer internal life, a more developed political culture and,

2. Andrew Thorpe, The British Communist Party and Moscow, 1920-1943 (Manchester, 2000). For discussion of the recent historiography, see John McIlroy and Alan Campbell, "Histories of the British Communist Party: A User’s Guide”, Labour History Review, 68 (2003), pp. 33-59. The sixteenth representative was the Russian, David Petrovsky.

3. The representatives resided in Moscow on a permanent or semi-permanent basis. They must be distinguished from communist leaders who represented their party on the Comintern Executive and its committees and would travel to Moscow for meetings but who were not resident in Russia, as well as members of national parties coopted to play a leading role in the Comintern apparatus. See Tables 2 and 4.

4. Célie and Albert Vassart, "The Moscow Origin of the French 'Popular Front", in Drachkovitch and Lazitch, Comintern, pp. 234-252, 246, quote Dimitri Manuilsky as saying: "You, Vassart, are the French ambassador in the Comintern."

5. Andrew Thorpe, "Comintern 'Control' of the Communist Party of Great Britain, 1920-43", English Historical Review, I I3 (1998), pp. 637-662, 646. 
among sections of the party, a stronger tradition of political heterodoxy. ${ }^{6}$ Properly grounded analysis of the differences and similarities between these two organizations and their contexts, analysis which transcends and might even lead to revision of such broad, rough and ready generalization, demands large-scale, monographic treatment if it is to avoid collapsing into superficial, juxtaposed outline essays which caricature comparative history. ${ }^{7}$

We can, nonetheless, progress towards such rigorous comparison through microcosmic scrutiny of particular aspects of different parties, especially where these aspects have sufficient in common to ground fertile comparative examination. In the context of their common affiliation to the Comintern and their common experience of Stalinism, exploration of the role of the representatives of different parties in Moscow may help shed light on broader questions of the relationship between centre and periphery. ${ }^{8}$ We shall therefore compare the British and French cases on the basis of this hypothesis: the greater political and social weight which the PCF possessed in France, and its more vigorous political life, suggests that its emissaries were more likely to exhibit a degree of political independence from the Comintern bureaucracy and to negotiate decisions than their opposite numbers in the CPGB.

Our exploration is in four parts. The following two sections, taking account of recent periodizations of the Comintern, document the background of the British representatives and examine their role, first as it took shape under Zinoviev and Bukharin's presidencies of the International, and second as it developed during the years of Stalinization. ${ }^{9}$ The third section provides information on the French group and makes some comparisons between the CPGB cohort and the permanent representatives of the PCF. Finally the paper summarizes our conclusions as to whether the British and French representatives were plenipotentiaries or servants of bureaucratic power.

6. For background, see for example, Annie Kriegel, The French Communists (Chicago, IL, 1972); Philippe Robrieux, Histoire interiéure du parti communiste, vol. I, 1920-1945 (Paris, 1980); Edward Mortimer, The Rise of the French Communist Party, I920-1947 (London, I984); Stephane Courtois and Marc Lazar, Histoire du Parti communiste français (Paris, 1995). For recent contributions on Comintern-PCF relations, see Serge Wolikow, "Le regard de l'autre: le Comintern et le PCF", in Narinsky and Rojahn, Centre and Periphery, pp.189-203, and Claude Pennetier, "Thorez-Marty: Paris-Moscou, Moscou-Paris", in ibid., pp. 203-219.

7. For an example of the problem, see Kevin Morgan and Marco Aurelio Santana, "A Limit to Everything: Union Activists and 'Bolshevik Discipline' in Britain and Brazil”, Scottish Labour History, 34 (1999), pp. 52-73.

8. Cf. the penetrating comments on the integrative role of Stalinism in Brigitte Studer and Berthold Unfried, "At the Beginning of a History: Visions of the Comintern after the Opening of the Archives”, International Review of Social History, 42 (1997), pp. 419-446, 434, 437.

9. For recent periodizations, see Kevin McDermott and Jeremy Agnew, The Comintern: A History of International Communism from Lenin to Stalin (Basingstoke, I996), pp. xxi-xxii; Jürgen Rojahn, "A Matter of Perspective: Some Remarks on the Periodization of the History of 


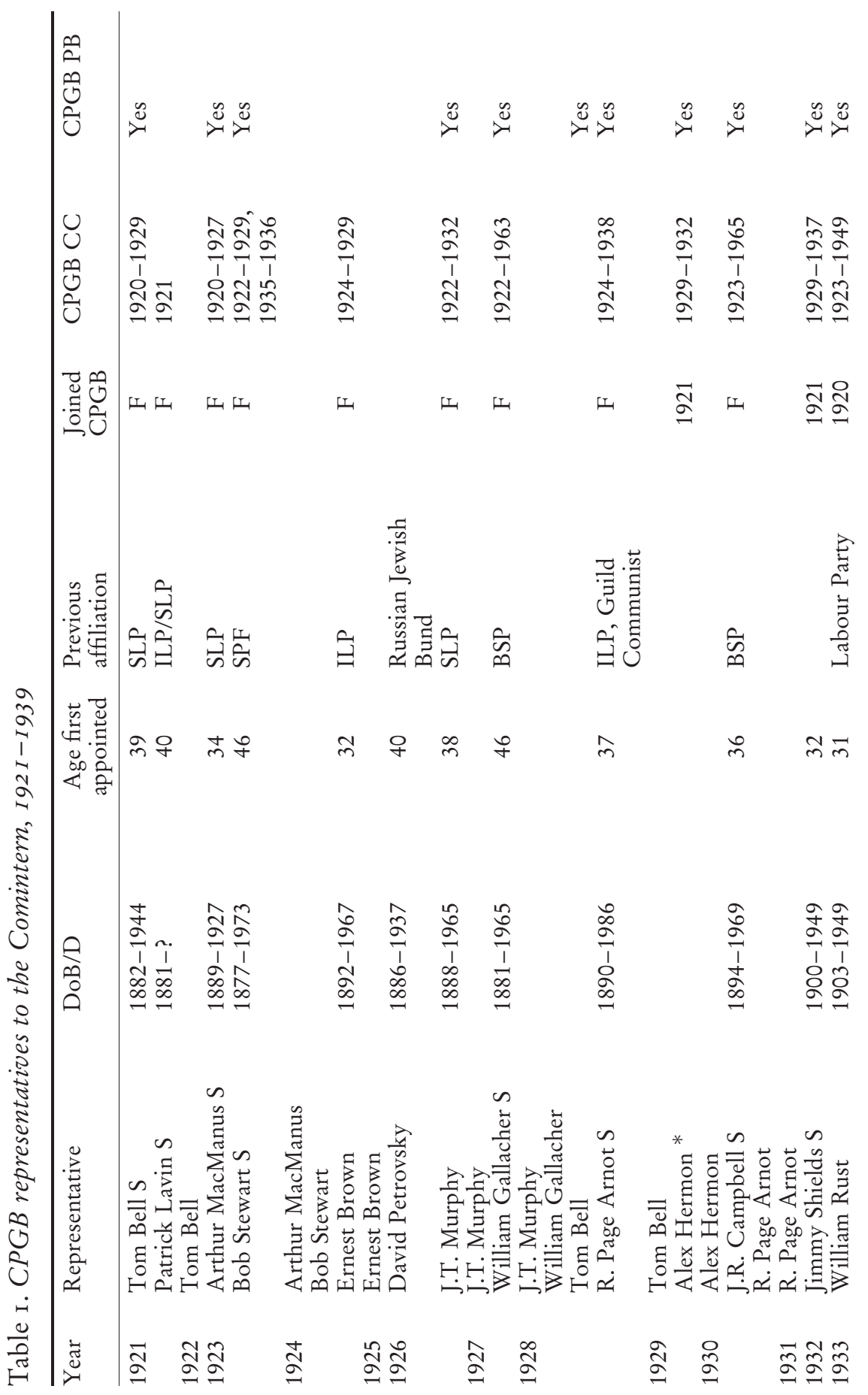




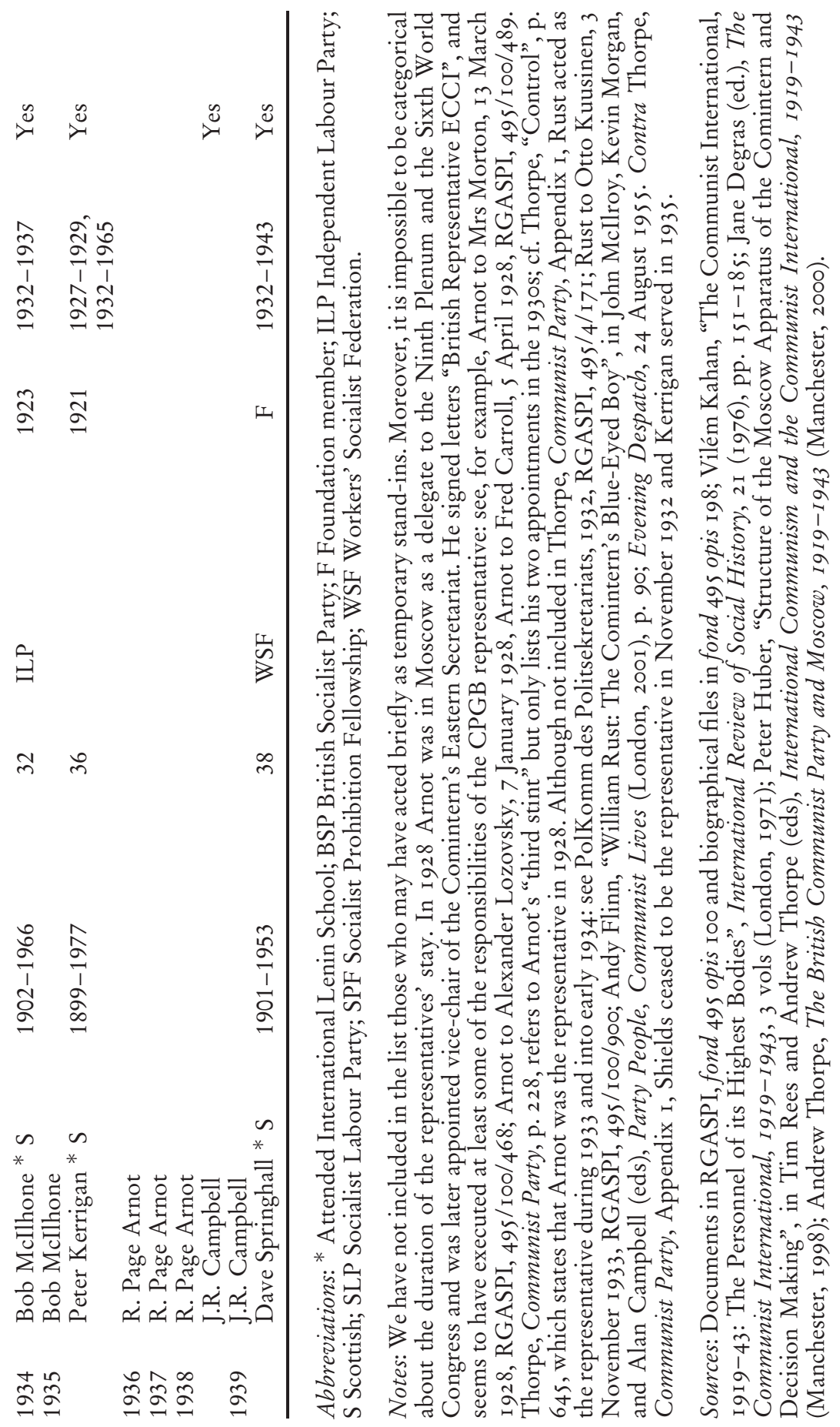




\section{FROM LENIN TO THE THIRD PERIOD, I $920-$ I 928}

The majority of British representatives in the early years were members of a pre-CPGB generation. ${ }^{10}$ They had matured before the 1917 revolution, although their politics developed qualitatively under its influence. Tom Bell, Arthur MacManus, Bob Stewart, J.T. Murphy, and William Gallacher were all born before I890. Coming from the working class and representing its skilled manual stratum, they possessed only elementary education. They came to political awareness in the first decade of the twentieth century against a background of growing industrial and political unrest and played a prominent role in trade-union and pacifist struggles in Scotland and the north of England during the I9I4-I9I 8 war (see Table I). Bell and MacManus were leaders of the small, intransigent industrial unionist Socialist Labour Party (SLP) which Murphy joined in 1917. Like them, Gallacher was a militant metal worker who had been a member of the British Socialist Party (BSP). While Stewart's grounding in the temperance movement was distinctive, he had been an activist in the carpenters' union, repeatedly imprisoned for his opposition to the war. All of this group were well known in the labour movement, founder members of the CPGB, worked full-time for the party and occupied key leadership positions before their service in Moscow. Such service was perceived in this period as a natural extension of party leadership. ${ }^{\text {II }}$ When he first went to Moscow, MacManus was the CPGB's president and best-known leader. Bell was its national organizing secretary, while Stewart, Murphy, and Gallacher had all been members of the Central Committee (CC) and of the Politbureau (PB).

In contrast, Patrick Peter Lavin, born in $\mathrm{I} 88 \mathrm{I}$ and generationally part of the above cohort, and the younger Ernest Brown (see Table I) were lesserknown socialist activists before i 920 . Lavin, an autodidact and former coal miner of Irish extraction, active in Irish republican struggles in Scotland, was associated with the SLP and ILP. He had translated a pamphlet by Lenin and part of Bukharin and Preobrazhensky's ABC of Communism from the German for the SLP, and was also involved in the short-lived Socialist Information and Research Bureau (DATA) in Glasgow. When he travelled to Moscow he had served on the CPGB, CC, and as secretary of

the Communist International", in Narinsky and Rojahn, Centre and Periphery, pp. 35-45; Wolikow, "L'Internationale communiste", pp. 20-23, 29.

I0. Biographical information in this paper draws on a wide range of sources, particularly the cadre files in the Russian State Archive of Social and Political History (RGASPI), fond 495 opis I98.

II. For the pre-CPGB period and the role of the future party representatives in both the wartime struggles and the foundation of the party, see Walter Kendall, The Revolutionary Movement in Britain, I900-192I (London, 1969); James Hinton, The First Shop Stewards' Movement (London, 1973); Raymond Challinor, The Origins of British Bolshevism (London, 1977). See also Thorpe, The British Communist Party, pp. 24-32. 
the Scottish Labour College. ${ }^{\mathrm{I} 2}$ Brown, a boot and shoe worker from Bingley, Yorkshire, imprisoned for his opposition to the war, joined the CPGB with the ILP left wing. Like Lavin, he journeyed to Moscow as a junior member of the top echelon: he was a member of the CC and had experience as a district organizer. ${ }^{\mathrm{I}}{ }^{3}$

The fact that Lavin was a temporary stand-in for Bell, and Brown a lastminute substitute because of demands on more senior candidates confirms that initially the party regarded the post as the prerogative of key leaders. It also underlines what would constitute a continuing constraint: that the paucity of cadres in what remained throughout the entire period a small, over-stretched organization required periodic improvization. This is affirmed by the brief appointment in 1926 of the Russian, David Petrovsky, at the time the Comintern representative in Britain, to represent the CPGB at the Comintern, a move which also emphasizes the extent to which its British section identified its interests with those of its parent body. ${ }^{14}$ Finally, it is noteworthy that all except Brown and Petrovsky were Scots; this highlights the important but still underresearched part which Scotland played in the infant party.

The CPGB initially conceived the appointment and recall of representatives as a party prerogative. In March I92 I the leadership wrote to the Comintern secretary Mikhail Kobetsky:

We wish it to be clearly understood that the mandate which Comrade Bell will carry cancels all previous mandates from the party in this country of every kind and that Comrade Bell is to be regarded as the sole representative in Russia of the Executive Committee of the Communist Party of Great Britain, such other comrades as are there at the moment $[\ldots]$ are in an entirely subordinate position to Bell. ${ }^{\text {s }}$

There seems to have been no objection to this procedure. But three years later CPGB headquarters was simply informed that MacManus, who was part of the delegation to the Fifth World Congress, would be remaining in Moscow as the CPGB representative, although the party responded by requesting that he continue there only for three months. Later in I924, the party was requesting, in somewhat different tones from those of I92 I, that Brown "be allowed to come to Moscow as the representative of the British

I 2. Ian MacDougall, Militant Miners (Edinburgh, I98I), p. 36; Patrick Lavin, "Questionnaire on United Front”, Communist Party Archive, Manchester (CPA), I995 microfilm; Thorpe, The British Communist Party, p. 42.

I3. Harry Pollitt to Presidium, ECCI, 22 November 1924, RGASPI, 495/100/17I. Brown was removed from the leadership in the Stalinization of 1929-1930.

I4. Petrovsky, also known as A.J. Bennet, lived in the USA before I9I7 and only joined the Bolsheviks after the revolution. As well as serving in Britain he also worked for the Comintern in France. He was arrested and liquidated in Moscow in 1937. His wife, the British Communist Rose Cohen, shared his fate. See Francis Beckett, Stalin's British Victims (London, 2004). I 5. MacManus and Albert Inkpin to Mikhail Kobetsky, is March I92 I, RGASPI, 495/100/27. 
Party". ${ }^{16}$ By $1926-1927$ the position, though never formalized, was shifting towards a Comintern veto: when the CPGB sought to recall Murphy, the Comintern successfully insisted that he must remain in Moscow. ${ }^{17}$ It is arguable that a convention had emerged which reserved the final decision to Moscow, a convention inadequately captured in the imprecise conclusion that the representative was "chosen by the British party in consultation with headquarters", ${ }^{18}$ with only occasional interference.

Despite the formality and legalistic language of Bell's appointment, the British representative was, and continued to be, one among a number of channels of communication and decision-making. At a formal level, there was the machinery of the Comintern in which CPGB leaders participated, including in this period relatively regular meetings of its Congress and Executive, supplemented by extended meetings (plenums) and commissions devoted to the British situation (see Table 2). There was, despite sporadic communication difficulties, continual direct traffic - letters, telegrams, reports, questionnaires, instructions - between the Comintern and CPGB leaderships and departments, while a series of transient and permanent Comintern emissaries in Britain, notably Mikhail Borodin and Petrovsky, reported directly to Moscow.

Initially, the Comintern cultivated direct links with prominent individuals in the party. The files contain various personal communications on the lines: "Saklatvala - come to Moscow with Newbold to discuss British and Indian problems". ${ }^{19}$ CPGB leaders such as Andrew Rothstein, whose father was a Russian minister, visited the Soviet Union regularly in the I920s; so did Murphy, who similarly corresponded with and reported to Comintern leaders from London, and so did other CPGB activists. ${ }^{20}$ Neither side paid great attention to constitutionalism. In 1923 there was a row about the Comintern leader, Ossip Piatnitsky, opening correspondence addressed to British representatives in Moscow. ${ }^{21}$ By the end of this period Gallacher was being instructed by the CPGB that a report was to be

[...] passed on to Comrade Stalin [...]. We think you will agree that it is not of a nature which would be primarily useful to the CI but is more one for

16. Harry Pollitt to Presidium, ECCI, 22 November 1924, RGASPI, 495/100/i7i; PB, is July 1924, CPA, CP/CENT/PC/or/O2; CC, 7 August I924, CPA, CP/CENT/PC/OI/03.

17. Murphy to CPGB PB, I 2 November 1926, RGASPI, 495/100/339; CC, 3,4 December 1927 , RGASPI, 495/100/417; Thorpe, The British Communist Party, p. I I I.

I8. Thorpe, "Comintern Control", p. 645.

19. General Secretary, Presidium, to Comrade Saklatvala, RGASPI, 495/100/94. Saklatvala and Newbold were CPGB MPs.

20. See, for example, Rothstein to Otto Kuusinen, 4 October 1924, and Rothstein to John Pepper, I9 December 1924, RGASPI, 495/100/I71; PB, 9 August 1926, RGASPI, 495/100/349; $\mathrm{PB}, 3$ January I928, RGASPI, 495/100/497.

21. ECCI to PB, CPGB, n.d., I923, RGASPI, 495/100/94. 
Table 2. British communists on Executive Committee of the Comintern (ECCI) and its committees

\begin{tabular}{|c|c|c|}
\hline 1920 & 2nd Congress & Tom Quelch \\
\hline 1921 & 3rd Congress & Tom Bell \\
\hline 1922 & 4th Congress & $\begin{array}{l}\text { Arthur MacManus, J.T. Walton Newbold (candidate } \\
\text { member) }\end{array}$ \\
\hline 1923 & 3rd Plenum & $\begin{array}{l}\text { MacManus (Presidium, Orgbureau); [Bob Stewart, } \\
\text { candidate, Orgbureau] }\end{array}$ \\
\hline 1924 & 5th Congress & $\begin{array}{l}\text { MacManus, Harry Pollitt; William Gallacher, Stewart } \\
\text { (candidate members); [J.T. Murphy, International } \\
\text { Control Commission] }\end{array}$ \\
\hline 1924 & 4th Plenum & $\begin{array}{l}\text { MacManus (Presidium, Orgbureau; candidate, } \\
\text { Secretariat); Pollitt (candidate, Presidium) }\end{array}$ \\
\hline 1925 & 5th Plenum & MacManus (Orgbureau) \\
\hline 1926 & 6th Plenum & Aitken Ferguson (Presidium, Secretariat, Orgbureau) \\
\hline 1926 & 7th Plenum & $\begin{array}{l}\text { William Gallacher, Murphy (candidate, Political } \\
\text { Secretariat) }\end{array}$ \\
\hline 1927 & 8th Plenum & $\begin{array}{l}\text { Gallacher (Presidium; candidate, Political } \\
\text { Secretariat), Murphy (Presidium) }\end{array}$ \\
\hline 1928 & 9th Plenum & $\begin{array}{l}\text { Gallacher (Presidium), Murphy (Presidium); Robin } \\
\text { Page Arnot, D. Petrovsky (candidates, Presidium) }\end{array}$ \\
\hline 1928 & 6th Congress & $\begin{array}{l}\text { Bell (Presidium, Political Secretariat), J.R. Campbell, } \\
\text { William Rust (for CYI; candidate, Presidium); Arthur } \\
\text { Horner (candidate member), Pollitt (candidate } \\
\text { member; candidate, Presidium) }\end{array}$ \\
\hline 1929 & 10th Plenum & $\begin{array}{l}\text { Bell (Presidium, Political Secretariat); Pollitt, Rust } \\
\text { (candidates, Presidium) }\end{array}$ \\
\hline 1931 & 11th Plenum & $\begin{array}{l}\text { Pollitt (Presidium, Political Secretariat), Arnot } \\
\text { (Presidium; candidate, Political Secretariat) }\end{array}$ \\
\hline 1932 & 12th Plenum & $\begin{array}{l}\text { Pollitt (Presidium, Political Secretariat), Arnot } \\
\text { (Presidium; candidate, Political Secretariat), Jimmy } \\
\text { Shields (candidate, Presidium) }\end{array}$ \\
\hline 1933 & 13th Plenum & $\begin{array}{l}\text { Gallacher (Presidium), Pollitt (Presidium, Political } \\
\text { Secretariat), Bob McIlbone (candidate, Presidium) }\end{array}$ \\
\hline 1935 & 7th Congress & $\begin{array}{l}\text { Gallacher (candidate, Presidium), Pollitt (Presidium); } \\
\text { Campbell, R.P. Dutt (candidate members); [Peter } \\
\text { Kerrigan, ICC }]\end{array}$ \\
\hline
\end{tabular}

Note: Names in italics denote those who were CPGB representatives in Moscow at some point during this period.

Source: Vilém Kahan, "The Communist International, I919-43: The Personnel of Its Highest Bodies”, International Review of Social History, 21 (1976), pp. I I-I85; Jane Degras (ed.), The Communist International, 1919-1943, 3 vols (London, I971).

information of leading comrades [...] so please pass it direct to JS. Impress upon him it is a private report. ${ }^{22}$

Through the early ig2os the representative's role remained relatively informal and far from tightly defined. This was reflected in the voyage to 
Moscow. Later visitants were able to fly. Bell had to stow away on a boat to Bremen before undertaking an exhausting train journey to the Soviet capital. The Comintern apparatus remained rudimentary: Bell participated in discussions of the Executive Committee (ECCI) and in the short-lived Anglo-American Colonial Section, addressed meetings across Moscow, and met and corresponded with Lenin. ${ }^{23} \mathrm{He}$ established what was to become the staple work of the representative, gathering and processing information from London to Moscow and vice versa, safeguarding London's interests by supervising British visitors, particularly those potentially critical of the CPGB or seeking Comintern favour, and acting as a one-man pressure group in advocating his party's demands for Soviet attention, funds, and resources. Despite the rats infesting the Hotel Lux, Bell benefited from his contact with the foreign communists who lived there, and his experience in Moscow sealed his identification with Russia: "Leaving the Soviet Union is a real wrench. I remember to this day the strange welling up of emotion. I experienced [...] just such emotions as I imagined the one-time emigrant experienced as they left their native land." 24

Lavin's short stint in Moscow, facilitated by his grasp of German, passed without recorded incident. He subsequently spent an unhappy period working for the Young Communist International in Berlin amid organizational and financial difficulties which prompted his resignation from the party. ${ }^{25}$ MacManus emulated Bell's record of dogged political conformity. But unlike that dour teetotaller, MacManus took full advantage of the rich social life of the Lux. The poet and novelist Claude McKay has left us a vivid picture of the mercurial Scot's "gargantuan boozing [...] there was a perpetually crucified expression on his countenance that all the Scotch whisky and Russian vodka in the world could not dispel”. ${ }^{26}$ As his teetotal successor, Bob Stewart, pointed out: "the Comintern was very much in its formative period and the communist parties of the various countries had various conflicts of opinion on many political questions". ${ }^{27}$ But the British party was not among them, and on all issues of political substance MacManus and Stewart were unimpeachably orthodox in their adherence to the line of the leadership of the Russian party. On the evidence of the archives, it was the meticulous

23. Thomas Bell, Pioneering Days (London, I94I), pp. 197-240; Bell and Wallenius statement, I June I922, RGASPI, $495 / 72 / 7$.

24. Bell, Pioneering Days, p. 242; Bell to Borodin, 7 August I 92 I, Bell to Kobetsky, 2 I July I 92 I, RGASPI, 495/100/27.

25. Letter from Patrick Lavin, I9 October 1923, RGASPI, 495/100/i i 7; PB, 5 November 1923 , RGASPI, 495/100/104; PB, 8 April 1924, RGASPI, 495/100/i 59.

26. Claude McKay, A Long Way from Home: An Autobiography (London, 1985 ; first published 1937), pp. 197-198.

27. Bob Stewart, Breaking the Fetters (London, 1967), p. I37. 
Stewart who introduced an element of consistency and formality into the job. Although communication was sometimes delayed and periodically difficult, he played a significant role in briefing the Comintern hierarchy on the British situation, on general elections, the position in the trade unions and the Labour Party, problems of CPGB organization, and the party press. Central to his work was the need "to keep the Comintern posted on what is taking place [...]. I have been deluged with enquiries for detailed information which I could not supply.”28

Committee minutes, he emphasized, were inadequate to contain the Comintern's increasingly insatiable thirst for facts. Conversely, he supplemented the role of the Comintern apparatus in sending directives to London: "Agitate widely against Cownpur charge. Show it is not conspiracy but is of a political character. Is persecution of Indian working class. Demand right of political organization Indian workers [...]. Call for intervention by Labour Government. Raise question in ILP conference."29 Amplifying and clarifying what was required, he alerted party leaders to future instructions and queries from Moscow on issues ranging from the fallibility of the party press in criticizing the Labour Party to the CPGB's methods of electing its leadership, and its failure to involve itself in the problems of the Swedish party. Stewart also attempted to monitor the implementation of Comintern decisions which, he emphasized, "are meant to be carried out". $3^{\circ}$

As well as keeping a discerning eye on British visitors, Murphy's contributions to a nonparty journal, and exchange of banners between textile workers in Oldham and Leningrad, Stewart bent much of his efforts, albeit with limited success, to money matters. Recording that he had got no further with Piatnitsky than MacManus had the previous year, Stewart provided advance notice and informed advice on financial problems:

[...] the Budget Committee has at last taken its decisions re. allocations for 1924 [...]. The position regarding Britain is the same as last year [...]. You will have to find some way of adding to the total or contract activity [...] with the allocation will come definite instructions to apportion at least one half between District organization and the paper. I incline to the idea that bigger grants to fewer people with maybe greater responsibilities and probably greater areas will be more advantageous [...]. The bigger problem still remains how to get money, and I think we should proceed on the assumption that the degree of outside assistance is a diminishing quality. ${ }^{31}$

The problems persisted. Two months later the prudent CPGB secretary,

28. Stewart to PB, 25 August 1924, RGASPI 495/100/1 50.

29. Stewart to PB, n.d., I924, RGASPI, 495/100/I 50.

30. Stewart to PB, I February 1924, RGASPI, 495/100/i 50.

31. Stewart to PB, 23 January 1924, RGASPI, 495/100/i 50. 
Albert Inkpin, who, perhaps because of external attention and internal tensions about money, asked Stewart to write about funds on a separate page in his letters as he did not file sensitive financial documents in his office, recorded:

[...] we urgently need your assistance in securing an immediate further payment on account of the first quarter's allocation. We are now nearly at the end of the quarter and have only received $£_{5} 00[\ldots]$. This is now practically exhausted and the need for money in a week or so will become very desperate. ${ }^{32}$

Stewart overcame language difficulties - English translation was introduced into the Comintern's deliberations - to play a full role in proceedings and was enlisted by the Comintern as an emissary to other European parties. He recalled meetings with Kamenev and Zinoviev and conversations with Stalin. Describing himself as "an apprentice Communist who listened and learned", 33 he attended meetings of the Russian party and met ordinary Russians. His daughter learned to speak the language fluently. His lifelong attachment to the CPGB and the Soviet Union was reflected in his later suspected leadership of the party underground in Britain. ${ }^{34}$

The scarcity of human resources in a tiny party reliant on Russian funds was underlined in 1925 when neither of the CPGB's two ECCI representatives, MacManus and Harry Pollitt, or the candidate member, Gallacher, could be spared from work in Britain. The Comintern's decision that while in Moscow Brown could attend ECCI meetings only in a consultative capacity reflected an unsatisfactory situation. ${ }^{35}$ Unsurprisingly, Brown followed in Stewart's footsteps as functionary rather than politician, interceding with Piatnitsky for more money, supervising British communists and undesirables such as W.W. Craik, the principal of the Central Labour College who had absconded to Moscow with its funds, and communicating and supplementing directives in a manner redolent of the "Bolshevization" of Zinoviev's Comintern. ${ }^{36}$ For example, he telegrammed Inkpin with regard to the CPGB's I925 Congress:

Theses too abstract construction methodologically wrong stop Chief error question of mass party common political tasks and Bolshevization treated as separate questions stop Political theses give insufficient analysis internal position of Great Britain stop No mention of actions and shortcomings government on

32. Inkpin to Stewart, 6 March I924, and 8, I 8 February 1924, RGASPI, 495/100/173; £500 at today's prices would be roughly equivalent to $£_{17,800}$.

33. Stewart, Breaking the Fetters, p. I37.

34. Source: Kasper, 3 I December 1946, National Archives, London, KV2/ I 8 I.

35. Inkpin to Secretariat, Comintern, I 8 June I925, RGASPI, 495/100/243; PB, 4 November I924, RGASPI, 495/100/i 59; ECCI to CC, CPGB, s December I924, RGASPI, 495/100/I 50. 36. Inkpin to Secretariat, Comintern, I6 July I925, RGASPI, 495/100/242; Stewart to Brown, I I December 1925, RGASPI, 495/100/243. 
budget question comma unemployed comma housing comma new tariffs comma insurance plan comma industrial peace and trade unions stop [...] My friends here entirely share this opinion stop Please note Brown. ${ }^{37}$

The tone of Brown's messages suggested a Russian rather than a Yorkshire author. But Inkpin was quick to puncture any illusions of grandeur: "Put out of your mind any thought of two months' holiday", he warned Brown. ${ }^{3}$ Like other party employees, the Yorkshireman would receive only two weeks' vacation. The representatives at this time, perhaps in acknowledgement of Russian conditions, received only 30 shillings [£I.5O] a week compared with Inkpin's $\mathfrak{£}_{260}$ per annum. However, this was raised to $£$ s per week, the quite substantial wage paid to CPGB fulltime workers, when British delegates were in Moscow for the World Congress. ${ }^{39}$ The representatives appear to have enjoyed a reasonably comfortable existence. Murphy negotiated his own salary before he sailed for Moscow with his wife and child and they were able to afford a Russian maid. $4^{\circ}$

Times had changed. The Lux no longer functioned on communal lines. There is little sense of Murphy or his successors mixing with ordinary Russians. Perhaps symbolically, the Comintern leader, Otto Kuusinen, lived just down the corridor, while as a portent of the future Georgi Dimitrov had the room next door. As Murphy recalled:

The Lux was the most interesting hotel in which I have ever stayed; it had Arnold Bennet's Grand Babylon beaten to a frazzle, not in its efficient service and external and internal grandeur, but in the human material which flowed through it. The stream was constant. The visitors came from the ends of the earth, workers, intellectuals, artists, ambitious politicians, revolutionaries, all vital, alive, intelligent, battling with ideas, some playing their own hand, others deputising for somebody else. Here were love affairs and tragedies, new political stars in the revolutionary firmament, damp squibs, fun, fights, storms, celebrations, conspiracies disclosures, jealousies, the clash of national customs, and such a variety of appearance that variety itself became commonplace [...]. ${ }^{\mathrm{I}}$

Murphy played a fuller role in the apparatus than any of his predecessors. He functioned as a representative of the Russian leadership in numerous aspects of Comintern activities. After the reorganization in I926, he worked in the British-American Secretariat which also covered Ireland, Australia, Canada, New Zealand, South Africa, and the

37. Brown to Inkpin, 30 May I925, RGASPI, 495/100/227.

38. Inkpin to Brown, 25 September 1925, RGASPI, 495/100/243.

39. Inkpin to Stewart, 27 June 1924, RGASPI, 495/100/173.

40. Mollie Murphy, Mollie Murphy: Suffragette and Socialist (Salford, I998), p. I02. Gallacher may have briefly carried out the representative's duties on Brown's departure; PB, 28 July i925, RGASPI, 495/100/233.

4I. J.T. Murphy, New Horizons (London, I94I), p. 242. 


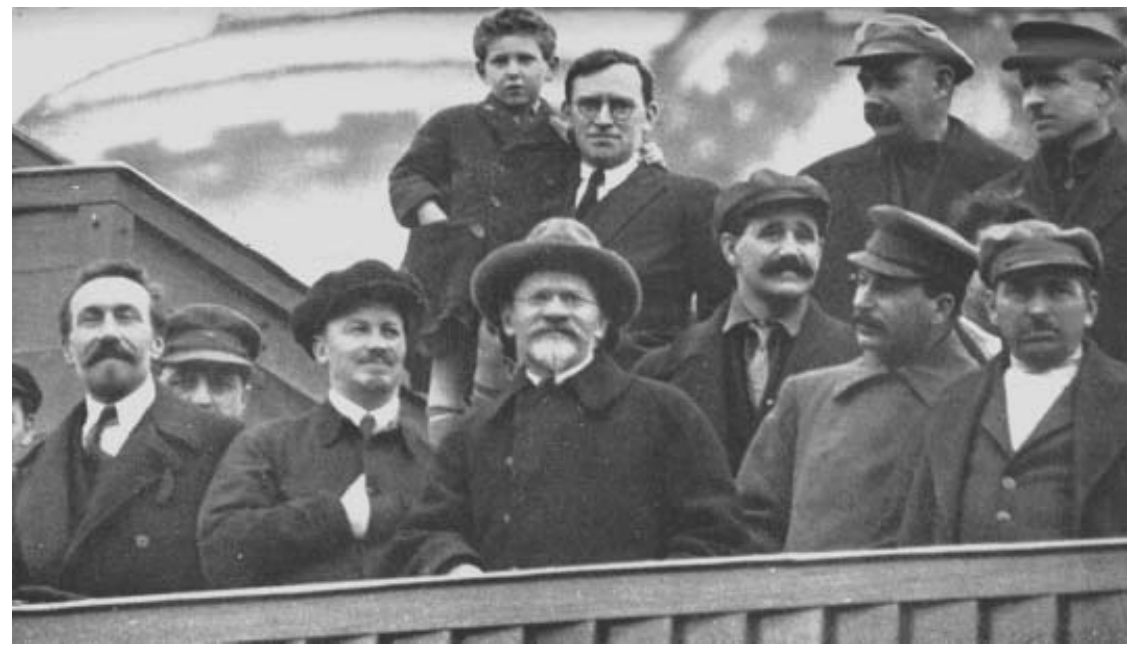

Figure I. Murphy, with his son Gordon, on Lenin's tomb on the tenth anniversary of the Russian Revolution, 1927. On the front row, left to right: Rykov, Bukharin, Kalinin, Ulganov, Stalin, and Tomsky.

From: J.T. Murphy, New Horizons (London, I94I).

Philippines. ${ }^{42}$ But he also served on the Presidium, the Political Secretariat, and the Eastern Committee. He remembered: "I was receiving an education such as I could get nowhere else". ${ }^{43}$ It was essentially an education in realpolitik. He demonstrated that the British representative could wield political influence. But it was influence wielded on behalf of the Comintern to shape the CPGB, rather than influence wielded on behalf of the CPGB to mould Comintern policy.

Despatched to Moscow by his party to defend its record on the general strike and the mining dispute, Murphy attacked that record. Expected to defend party objections to publishing the Soviet trade unions' manifesto criticizing the British union lefts, and by implication the CPGB, over the general strike, Murphy capitulated when confronted by Stalin at the August 1926 Presidium. By September he acknowledged that Stalin was right and the CPGB mistaken. Together with Arnot, he wrote, at the instigation of Kuusinen, an article for the Communist International criticizing the CPGB's right-wing errors. By May 1927 his reliability was such that he was accorded the cameo role of moving the expulsion of Trotsky and Voja Vuyovitch from the ECCI.44

42. See Grant Adebikov and Eleanora Shakhnazarova, "Reconstructions of the Comintern Organisational Structure", in Narinsky and Rojahn, Centre and Periphery, pp. 65-73, 67-68.

43. Murphy, New Horizons, pp. 248, 239.

44. Ralph Darlington, The Political Trajectory of J.T. Murphy (Liverpool, I998), pp. I43-I I; 
Despite this prominence, Murphy was untiring in relaying directives and advice to the CPGB on a wide variety of matters, from the Conservative government's legislative programme to relations between the British and Russian governments and the situation in China and Indonesia. ${ }^{45} \mathrm{He}$ played his part in supporting the Comintern's analysis which produced from 1926 a hardening of CPGB policy towards the union leaders and eroded its traditional critical support for the Labour Party in general elections. His packed agenda also involved the now conventional lobbying for additional funds as well as the novel duty of representing the ECCI on the board of the International Lenin School (ILS). ${ }^{46}$

But his tenure explicitly raised the tensions in the dual loyalty which representatives owed to the CPGB and the Comintern. Gallacher, who briefly succeeded Murphy, inquired at the ECCI Presidium in November 1927 whether the latter was acting for the British party in Moscow or representing the Comintern in its relations with London. ${ }^{47} \mathrm{He}$ would swiftly discover and adapt his own practice to the anachronism of any such distinctions. Initially deploring the irrelevance of the first portents of the Third Period to the situation in Britain, within a matter of months Gallacher had become one of its most vocal advocates. Educated out of ultra-leftism by Lenin in 1920 at the Second World Congress, he was reinserted back into it by Stalin and carried Moscow's sectarian message back into the CPGB, just as Murphy had done..$^{8}$

The British representatives arrived in Moscow already inspired by faith in the Soviet Union and its leadership. None in this period spoke Russian, although Murphy claimed a smattering. They were reliant on translators and the treacheries of translation - as well as the official apparatus for much of their understanding of this new closed, privileged world, and they lacked any independent resource base. Moreover, the demands of CPGB activity in Britain ensured that representatives rotated and their tenure and experience was relatively brief. Brown and Stewart served approximately a year; Bell and MacManus were there in total for less than that; Gallacher's tour of duty in Moscow lasted some six months; Lavin's sojourn was even

J.T. Murphy and R. Page Arnot, "The British Trades Union Congress at Bournemouth", Communist International, is October 1926.

45. Darlington, Political Trajectory of J.T. Murphy, pp. I I I-162.

46. Report to Presidium, ECCI, 28 November I 927 , RGASPI, 495/100/4I I; THW [Wintringham] to Murphy, 27 January I927, A. [Inkpin] to Murphy, 4 February I 927, RGASPI, 495/100/ 425. For the ILS, see John McIlroy, Barry McLoughlin, Alan Campbell, and John Halstead, "Forging the Faithful: The British at the International Lenin School", Labour History Review, 68 (2003), pp. 99-I 28.

47. ECCI Presidium, 22 November 1927, RGASPI, 495/100/4II. For Gallacher, see his not always reliable recollections: William Gallacher, Revolt on the Clyde (London, 1936); The Rolling of the Thunder (London, 1947); Last Memoirs (London, 1966).

48. For his leading role in the formation of the red union, the United Mineworkers of Scotland, see, for example, PB, I8 September 1928, RGASPI, 495/100/498. 
shorter. It is scarcely surprising that they exhibited minimal political independence and there was little stimulus from the CPGB for them to do so. The only prolonged appointment was, perhaps significantly, Murphy's eighteen months, and he was the only representative to become a prominent public actor within the apparatus and take up the cudgels for it in a disagreement with his own party. For the rest, their role was substantially a reactive one.

In relation to Serge Wolikow's questions concerning the future career progression of representatives, the experience plausibly intensified allegiance to Soviet Russia. ${ }^{49}$ However, it is difficult in these years to discern service in Moscow as an important factor in advancing political destinations. The majority of the representatives continued in the CPGB leadership in similar fashion before and after the interlude. It is arguable that MacManus, who died in I927, was less prominent, although this was related to personal factors, but Bell and Gallacher continued in much the same way as before in the aftermath of their return. Moreover, the changes in their fortunes, Bell's decline after 1929 and Gallacher's prominence as an MP after 1935, related to different conjunctural factors. Murphy perhaps perceived the part he had played in Moscow and the knowledge of the Comintern he had gained there as lubricating further advancement at home. But, as the troubled path which culminated in his expulsion from the CPGB in 1932 confirms, neither his fellow leaders nor, crucially, the Comintern, shared his assumptions. The rise in the CPGB of figures such as Pollitt and Rajani Palme Dutt, who had not filled this role but who had plied other routes to Moscow and established contacts there, and the resignation of Lavin and the failure of Brown to subsequently secure promotion, suggest the limitations of the role as a passport to preference in the CPGB. ${ }^{\circ}$

\section{THE BRITISH REPRESENTATIVES AND STALINIZATION}

Of the nine permanent representatives of the CPGB in Moscow during the decade from 1928 (see Table I), three of the first four - Bell, Arnot, and J.R. Campbell - constitute a transitional group spanning the initial period of Stalinization. Forty-six years of age in I928, Bell was now struggling to keep abreast of swift-moving political developments. Arnot, thirty-seven years of age on his first appointment, and Campbell, thirty-six years old, were likewise party founders and members of the pre-CPGB generation. A former ILP member and Guild Socialist and the driving force in the influential Labour Research Department, Arnot joined the party leader-

49. Wolikow, "L’Internationale communiste", p. 84.

50. For Murphy's resignation/expulsion see Darlington, Political Trajectory of J.T. Murphy, pp. $205-216$. 
ship in 1924 while Campbell was a Cooperative Society clerk drawn to the socialist movement in Glasgow as a teenager in I9I2. Volunteering for military service in I9I 4, a fact his antagonists rarely overlooked, he became active in the postwar Clyde Workers' Committee. Nonetheless, he belongs to a different category of activist from the former rank-and-file leaders such as Bell and MacManus, for he spent almost his entire adult life working for the CPGB and entered its leadership in I923, a little later than they did. While Arnot was careful to stress that he came from a workingclass background, his father, a weaver, became a journalist. Arnot received a university education and subsequently worked as a journalist and researcher before joining the CPGB. From a working-class family, Campbell was briefly a member of the black-coated proletariat.

The remaining six representatives were, like their predecessors, from the working class and possessed minimal formal education. Unlike their predecessors, they were members of the Stalin generation. Born around I900, they became aware of the Russian Revolution in the context of war weariness when they were entering adult life and were politically impressionable and malleable. Their politics developed around, and after, the formation of the CPGB; their horizons had been largely bounded by it, and their experience of leadership within it was a product of the Stalinization of the late I920s. In keeping with the times, three were ILS graduates, while a fourth subsequently attended the school.

Alex Hermon was an electrician and a raw, relatively inexperienced activist in the Electrical Trades Union in London, while Jimmy Shields, a brass moulder from the party's stronghold in Greenock, Scotland, had served briefly as secretary of the tiny Communist Party of South Africa in the mid-r920s. With Hermon, he was among the young, intransigent workers drafted on to the CC in 1929 in accordance with the requirements of the Comintern's ultra-left turn. William Rust, usually viewed as a quintessential Stalinist and bureaucrat par excellence, joined the CPGB soon after the party's formation. He represented the Young Communist League on the CC from 1923, and benefited from Stalinization to become an important part of the leadership in I929. The son of a bookbinder who became an office worker and a member of the Labour Party, when he journeyed to Moscow in late 1932 his star was descending.

Bob McIlhone, a Lanarkshire steel worker, joined the CPGB in 1923 after a few months in the ILP. Following study at the ILS, he was appointed Sheffield organizer before travelling to Moscow in I934. Peter Kerrigan, a skilled metal worker, had significant experience as an engineering shop steward in Glasgow before joining the CC in 1927. He was unusual in that he briefly left the CPGB in 1922 in opposition to its concessions to the Labour Party over the united front. However, after nine months at the ILS, he was appointed the CPGB's Scottish secretary in 1930 and became noted for implacable Stalinist rectitude. The final 
representative, Dave Springhall, was another ILS graduate and unshakeable Stalinist. An assertive Londoner, Springhall was a former naval rating, dishonourably discharged for political agitation, who had been on the party payroll since becoming a leading member of the Young Communist League in 1923. Finally, we should again observe that with the exception of Rust, Springhall, and Hermon, the post-1929 cohort was Scottish.

The Stalinization of the Comintern documented by Studer stimulated further accretion of power at the summit, accompanied by increasing subjection of the formal structure to the secret apparatus and the NKVD. ${ }^{\text {I }}$ Vistas of the Comintern as a panopticon owned by the Russian state, generating inside knowledge of national parties, burgeoned. From I929, the minutes of the Anglo-American Secretariat (AAS) attest to the aspiration of the Comintern for greater efficiency, vision, and reach. The detailed criticisms and instructions which flowed from Moscow to London had input from Bell and Petrovsky, but also from the Russian party cadres Mingulin, Safrov, and Fineberg before they were vetted and finalized at high levels by the Comintern leaders Manuilsky, Piatnitsky, and Kuusinen. Reports were received and reviewed not only from CPGB headquarters but from its districts and its activities, and press subjected to more detailed scrutiny. Bureau meetings were on occasion chaired by Bell but Comintern representatives were present and vocal. A new factor was the attendance and involvement of the ILS students, the assault troopers of Stalinism..$^{22}$

Bell was a convert to Third-Period policies who sought to induct the CPGB into the new Stalinist order, albeit in a less abrasive manner than Murphy. His role was constrained by the intensification of control over the Comintern by the Russian state, and the detailed reports of the increasing number of agents and instructors it placed in Britain. As the native face of Moscow supervision, Bell emphasized the new position: "There is a very critical attitude here towards the new Central Committee and the PB. And you can rest assured that any failure wholeheartedly to carry out the new line will not be allowed to pass." 33 Even relatively minor matters, such as the editing of letters from champions of ultra-leftism in the party press, were noticed and taken up: "I have already explained to you how critical everyone here is of the party leadership and such an

5I. Studer, "More Autonomy for the National Sections?", pp. I02-II3; Peter Huber, "The Cadre Department, the OMS and the 'Dimitrov' and 'Manuil'sky' Secretariats during the Phase of the Terror", in Narinsky and Rojahn, Centre and Periphery, pp. I22-152; Neils Erik Rosenfeldt, Stalin's Secret Chancellery and the Comintern (Copenhagen, I99I).

52. For example, see AAS, 21 October 1929, RGASPI, 4945/72/52; AAS, I 9 January 1934, RGASPI, 495/72/256. For discussion of recent writing on the Third Period in Britain, see John McIlroy and Alan Campbell, "For A Revolutionary Workers' Government': Moscow, British Communism and Revisionist Interpretations of the Third Period, 1927-1934", European History Quarterly, 32 (2002), pp. 536-569.

53. Bell to CPGB, I March 1929, RGASPI, 495/100/585. 
unwarranted interference with a letter sent as a contribution to the discussion makes a very bad impression." 54

Bell also relayed Comintern directives and his personal estimations of the way the wind was blowing in Moscow: "General opinion mistakes wrong formulation in all resolutions stop Example estimation prospects stabilization and influence on groups of workers stop Affiliation campaign and liberalization stop Insufficient criticism analysis left turn, Maxton etcetera stop Still clinging to old line." s5 The CPGB leadership did its best to act on these injunctions, sometimes requesting advice from the highest authority. Bell's deference to power contrasted with his firmness with his hapless comrades:

Dear Comrade Stalin,

For the last few weeks I have been anxious to get some decisions concerning the coming General Election in Great Britain. The Party is insisting that some political help in the coming campaign should be given from here. I am fully aware of your many obligations at the present time, but I consider the present situation with regard to the British Party so urgent, that I am asking you to spare me a little of your time. ${ }^{6}$

Bell was in turn the subject of supplications from the new, Russiansponsored party leader, Pollitt, concerning the perennial issue of more money, particularly to support the new red unions; he also took a keen interest in the fortunes of the British students at the ILS. He appears to have been assiduous administratively and, to the best of his ability, politically. But despite novel denunciations of "the hidebound traditions of an old leadership steeped in the opportunism of the Second Period", 57 in strident phrases that would have done credit to any Young Turk, he was perceived in London and Moscow as an irredeemable component of what Manuilsky contemptuously viewed as the old, ineffective, and pre-Stalinist "society of great friends". ${ }^{8}$ The Comintern did nothing to save Bell as he was purged from the CPGB leadership for the "mistakes" he had made at the Tenth ECCI Plenum in July 1929.59

That experience and competence could, in the years of "class against class", constitute a handicap was further illustrated by the approval of the appointment of Hermon, hardly a cadre, as Bell's successor by the Comintern Political Secretariat. Until his return to London in the summer

54. Bell to Inkpin, I4 March 1929, RGASPI, 495/100/585.

55. Bell to Inkpin, 8 January I 929 , RGASPI, $495 / 100 / 585$.

56. British Representative to Comrade Stalin, 3 April I929, RGASPI, 495/100/585.

57. Statement by Comrade Tom Bell on the Congress of the CPGB, 17 December 1929, RGASPI, 495/100/596.

58. Inprecorr, 25 September 1929.

59. See note 57 above; Leslie J. Macfarlane, The British Communist Party: Its Origins and Development until 1929 (London, 1966), pp. 239-240. 
of I930, Hermon worked in tandem with Campbell, despatched to Russia for "straightening out" after his "right" deviations. Hermon seems to have spent a very brief period in Russia and was subsequently the party's sole representative at the 1930 TUC Congress. ${ }^{60}$ With Campbell, he sought to alert the CPGB leadership to what Moscow perceived as "dangers", such as Pollitt's support for the idea of a breakaway British miners' union, and inevitably he directed his efforts to financial sustenance as, propelled by ultra-leftism, CPGB membership collapsed. ${ }^{61}$

Arnot was a canny Cominternist. His diplomatic skills honed through work with trade-union leaders and the left intelligentsia since 1914, he worked in harness with Mingulin but was closely supervised by, and on issues of significance took counsel from, the Comintern hierarchy. $\mathrm{He}$ made explicit that he perceived his primary role as communicating and expanding upon Comintern thinking. He explained to Pollitt in I93 I how the system worked:

No political wire was sent by me (other than on some question of detail) except after consultation with other. Since J.R.C.[ampbell] left there has been much closer working here and along the lines of a detailed plan of work with an endeavour to follow the activities of each Party very closely. The idea is that the CI should come in not as hitherto often after events have taken place but as far as possible by a more current connection [...]. Personal telegrams for which I shall have sole responsibility I shall sign Page. This endeavour on the part of all the Secretariats [is] to get into closer touch with the Parties and where a Party is judged to have no difference in its line with the line of the Comintern but where the results of work along a correct line have not yet built a mass party to take up all questions of organization, questions of tactics, actual carrying out of line, etc, etc. $^{62}$

That Arnot was typically speaking with the Comintern's voice is clear from his correspondence. Authoritatively brushing aside Pollitt's complaints about lengthy telegrams, he asserted:

Surely, you [...] realize that those telegrams are sent off in my name only after the most detailed consideration both of the contents and the actual text and wording

60. AAS, I8 December 1929, RGASPI, 495/72/52. Hermon was in London in February and March 1930 and had finally returned by August; PB, 26 February, 7 March, I3 August 1930, RGASPI, 495/100/673. The view that the Comintern despaired of Hermon is based on slender evidence and other British representatives were similarly criticized for lack of diligence in pursuing matters: see Pollitt to McIlhone, 20 November 1934, RGASPI, 495/100/943; Thorpe, The British Communist Party, p. I60.

6I. Campbell and Hermon to Pollitt, i6 April, 8 May i930, RGASPI, 495/ı00/663; Hermon to Pollitt, 23 May 1930, RGASPI, 495/100/648; Pollitt to Hermon, 2 May, Harry to Johnny and Alec, 23 June 1930, RGASPI, 495/100/68 5. Given his deviations, Campbell's candidature was only carried after a vote on the $\mathrm{PB}$ and a letter to the Comintern emphasizing that Hermon was the senior representative. PB, 20 March I930, RGASPI, 495/100/675.

62. Arnot to Pollitt, is February i93 I, RGASPI, 495/100/738. 
by the members of the Political Commission. I wish that we gave one-tenth of the attention to the actual wording of what we send to the district committees that the Comintern gives to the wording of what it sends to the British Party [...]. If those telegrams are not helpful, it would be very useful to have critical remarks about them and not simply abuse. But I would suggest that whatever criticism has to be made should be made rather carefully; for last year, at the British Commission, the complaint was made that the Comintern does not help enough. ${ }^{6}$

To ensure such help, Arnot assiduously conveyed in detail Comintern criticism and instruction on the CPGB's industrial policy, the united front from below, the failure of the party press to give sufficient attention to Russian matters, and the progress of the ILS students. He emphasized the Comintern's insistence on postponement of the party's I93 I Congress, “an absolutely correct decision", and the need to root out social democratic ideas about the need for regular meetings of party bodies. ${ }^{64}$ Arnot advised on every aspect of the handling of the persecution of the deviant British communist, Arthur Horner. For example, every district was instructed to convene a conference to discuss the CC decisions on Horner with reports to be given by PB and CC members "and not district organizers". 65

It seems to me that it would be better for the $\mathrm{PB}$ not to propose the expulsion of Horner but to lay all the facts before the CC, to get his reply and on the basis of his reply towards the end of the meeting and only then to propose the expulsion when it is seen to be fully warranted [...]. Strongly advise any decision on Horner should not be made operative [...]. He will first receive a letter from here and if then within a definite time he does not give a satisfactory answer the decision should automatically come into force [...] meantime intensify campaign against opportunism in all cells and locals [...]. This telegram for Polbureau only. ${ }^{66}$

Arnot represented the spirit of the times in his criticism of what were, in Third-Period terms, "unreliable elements", such as Horner, his friend the equally "right-wing" unemployed leader, Wal Hannington, the disgraced former Comintern acolyte, Andrew Rothstein, and in Moscow the independent thinking referent, Freda Utley - whom he suggested should be replaced for unwarranted criticism of the CPGB - as well as Joe Fineberg, an old BSP member who had worked in the Russian apparatus for many years. ${ }^{67}$ In consequence of the vigorous campaign against deviants,

[...] all those comrades whose opportunist line was so strongly condemned by the XI Party Congress and by the Comintern, and of whom many have been lying

63. Arnot to Pollitt, 3 March i93 I, RGASPI, $495 / 100 / 739$.

64. Arnot to Pollitt, 8 August 193 I, RGASPI, 495/100/739.

65. Arnot to Pollitt, i9 June 193 I, RGASPI, $495 / 100 / 739$.

66. Arnot to Pollitt, Io, is May i93 I, RGASPI, 495/100/738.

67. Arnot to Pollitt, is February i93 I, RGASPI, 495/100/738. 
doggo up till now, should be compelled by pressure from below of the party membership to make a clear statement of where they stand. ${ }^{68}$

Arnot also reported on Russian developments. He informed Pollitt about Stalin's purge of the distinguished student of Marx, David Riazanov, and observed that in the Russian party "there is an inner-party situation characterized by a new group headed by Sirtsov, Lominadse, and Shatskin which has striven and plotted against the line of the CC, but I am told it will easily be liquidated". ${ }^{69}$ Arnot's mentors proved prescient. ${ }^{70}$

Changes in the Comintern apparatus formalized in 1935 were taking shape earlier. When Shields arrived in early 1932, centralization, bureaucratization, scientific management, and Taylorism were already discernible. The AAS consisted of twelve members, three of whom were Russians, while nine Comintern representatives, headed by Manuilsky, Kuusinen, and Piatnitsky were invited to meetings together with representatives of the Profintern, the Communist Youth International, the ILS, the Institute of Red Professors, and Pravda. But the smaller bureau led by Mingulin was the working group, subordinate to the political secretariat, and its directives were detailed and carefully crafted, as earlier practice was confirmed and extended: "Draft letter to CPGB on antiwar campaign: Comrade Tom to alter letter in accordance with discussion, after which it is to be sent to Great Britain signed by Comrade Shields." 7 r The letter protested about London's delay in sending material and deplored the small size of demonstrations and the party's failure to mobilize. Such was the level of penetration that Shields even lamented the absence of antiwar propaganda in the Dockland Leader, organ of the Stepney Communist Dock Group, and demanded that the CPGB "use facts and quotation from the bombardment of Nanking and Wan-Tsien in 1926 by British warships, and quotations of the role of Britain during imperialist intervention against the USSR which are published in such books as General Graves, 'American Siberian Adventure"”..$^{2}$

Shields was taken up with the new panoptic obsession with "verification" of cadres based on autobiographical profiles and preparing reports on party personnel, as the AAS resolved to comb all important CPGB documents since I929 in the context of examining its press, education provision, and illegal apparatus. ${ }^{73}$ Relations with the ILP, factory cells,

68. Arnot to Pollitt, I9 June I93 I, RGASPI, 495/100/739.

69. Arnot to Pollitt, I6 November 1930, RGASPI, 495/100/663.

70. Branko Lazitch and Milorad Drachkovitch (eds), Biographical Dictionary of the Comintern (Stanford, CA, 1973), pp. 234-235, 365-366.

7I. For Harry and Mac, 28 March 1932, List of Comrades to be Invited to Anglo-American Secretariat Meetings, I4 April i932, AAS, 27 March 1932, RGASPI, 495/72/I47.

72. For Harry and Mac, 28 March I932, RGASPI, 495/72/I 47.

73. Plan of Work Regarding Cadres in Great Britain, AAS, 29 March I932, RGASPI, 495/72/ I 47 . 
concentration areas, and the ILS received sustained, intensive scrutiny while campaigns against heretics, notably Murphy, somewhat incongruously expelled for raising the issue of British government credits to Russia, came in for critical attention and castigation: "It must never occur again that the theoretical organ of the party [which Murphy edited] is issued without previous control of the PB. The campaign of enlightenment against Murphy took place much too late."74

The young Scot's appetite for information on behalf of the Secretariat was inexhaustible:

I would like to be sent precise details with regard to the composition of the new membership who recently joined the party and what success we are having in retaining them. Also concerning the Lucas strike, please send me all information concerning the conduct of the dispute and the nature of our proposals regarding what should be done with the Lucas workers concerning trade union activity after the strike. ${ }^{75}$

Five days later he wrote complaining that he had received no information for weeks on how CPGB work was progressing, "especially in the concentration districts [...] send us a letter as soon as possible". ${ }^{76}$ Shields's time was also occupied with Pollitt's continuing grumbling about money and administrative issues, while information sent from Moscow to London naming British Trotskyists stimulated requests for Shields to turn his inspection tower around and fix his gaze on possible dissidents among CPGB members in Moscow: "I want you to get a line on Freda Utley, Jane Tabrisky, and Michael Ross." 77

Rust's stay, which extended into 1934 and involved his replacement by Shields as editor of the Daily Worker, followed a similar course. However, it was dominated by the move away from the Third Period and attempts to ensnare the ILP in the coils of the Comintern..$^{8}$ McIlhone's tenure witnessed the monitoring in Moscow of all significant aspects of policy, from the move to the United Front, to the Popular Front, to the detail of the party MP Willie Gallacher's speeches in Parliament. The two-way flow of information was sustained, with Pollitt anxious to receive a lead on a wide variety of issues:

When will the CI make a pronouncement on the sending of the troops to the Saar? Surely this is an event that demanded a line from the CI [...]. We want to publish an alternative programme to the Labour Party statement now out. You

74. J. Shields, Draft of a Letter to the CPGB on Campaign on Murphy's Desertion from the Party, I 3 June $1932,495 / 72 / 147$.

75. Shields to Pollitt, 22 February 1932, RGASPI, 495/100/8 I4.

76. Shields to Pollitt, 27 February I932, RGASPI, 495/100/8 I4.

77. Pollitt to Shields, I7 August 1932, RGASPI, 495/100/853.

78. See, for example, the documents in RGASPI, 495/100/889, 495/100/891, 495/100/91 I; and Rust to Kuusinen, 3 November 1933, RGASPI, 495/100/900. 
have a first draft. We must have your opinion [...] we have not yet received the directives as to the basis for the election of Congress delegates [...] it is clear that the line on the [on the united front with Labour] has come as a bombshell.79

But the situation was changing. There was now a radio link between Pollitt and Moscow facilitating transmission and reception of messages on key issues, while reorganization saw the AAS replaced by the Marty Secretariat and the representative's role as a subordinate technician confirmed:

The main task of the representatives is to carefully follow the whole life of the country and work of the Party which they represent, to take the initiative in raising actual questions and take part in the elaboration and preparation of proposals [...]. In the first working day of each week, Comrade Marty receives information on all countries. Information to be given by the respective Party representatives. ${ }^{80}$

Centralization and Taylorism affirmed the role of the representative as a secondary functionary: "No organizational or political measure can be carried in the Secretariat [...] without discussion or approval of Comrade Marty who bears responsibility for the work of the whole Secretariat before the ECCI." $8 \mathrm{r}$

The representatives developed their pre-existing allegiance to the Comintern and increasingly internalized the values and codes of the redesigned organization they worked for. Dual allegiances were ultimately resolved in favour of the Comintern. ${ }^{82}$ From 1935, their work was increasingly conducted against the background of the terror. Kerrigan, who briefly replaced McIlhone in the summer of that year, was already nitpicking at the Daily Worker's coverage of the fall of Stalin's former acolyte, Abel Yenukhidze, and insisting on "really careful scrutiny of all articles and news items by comrades who are not only politically capable but also know the subject matter they are checking". ${ }^{83}$ There was similar touchiness in the Comintern at what was seen as a slighting reference to Nikita Khrushchev: "A certain Khrushchev' happens to be the secretary of the Party for the Moscow District." ${ }_{4}$ Kerrigan also emphasized Moscow's political correctness in all things: “The use of the term 'nigger' has been repeatedly condemned and we should not allow such bad formulations [...] especially as it appears twice in half a dozen lines." ${ }^{85}$

79. Pollitt to McIlhone, 19 March, 27 July, 20 October 1934, RGASPI, 495/100/943.

80. Distribution and Methods of Work of Political Collaborators of Secretariat of Comrade Marty, 2 December 1935, RGASPI, 495/14/3.

8. Ibid.

82. Cf. Studer, Un parti sous influence, p. 259.

83. Kerrigan to Dear Friends, 26 June I935, RGASPI, 495/20/44.

84. Kerrigan to Dear Friends, I7 June I935, RGASPI, 495/20/44.

85. Kerrigan to Johnny and Bill, 22 June I935, RGASPI, 495/20/44. 


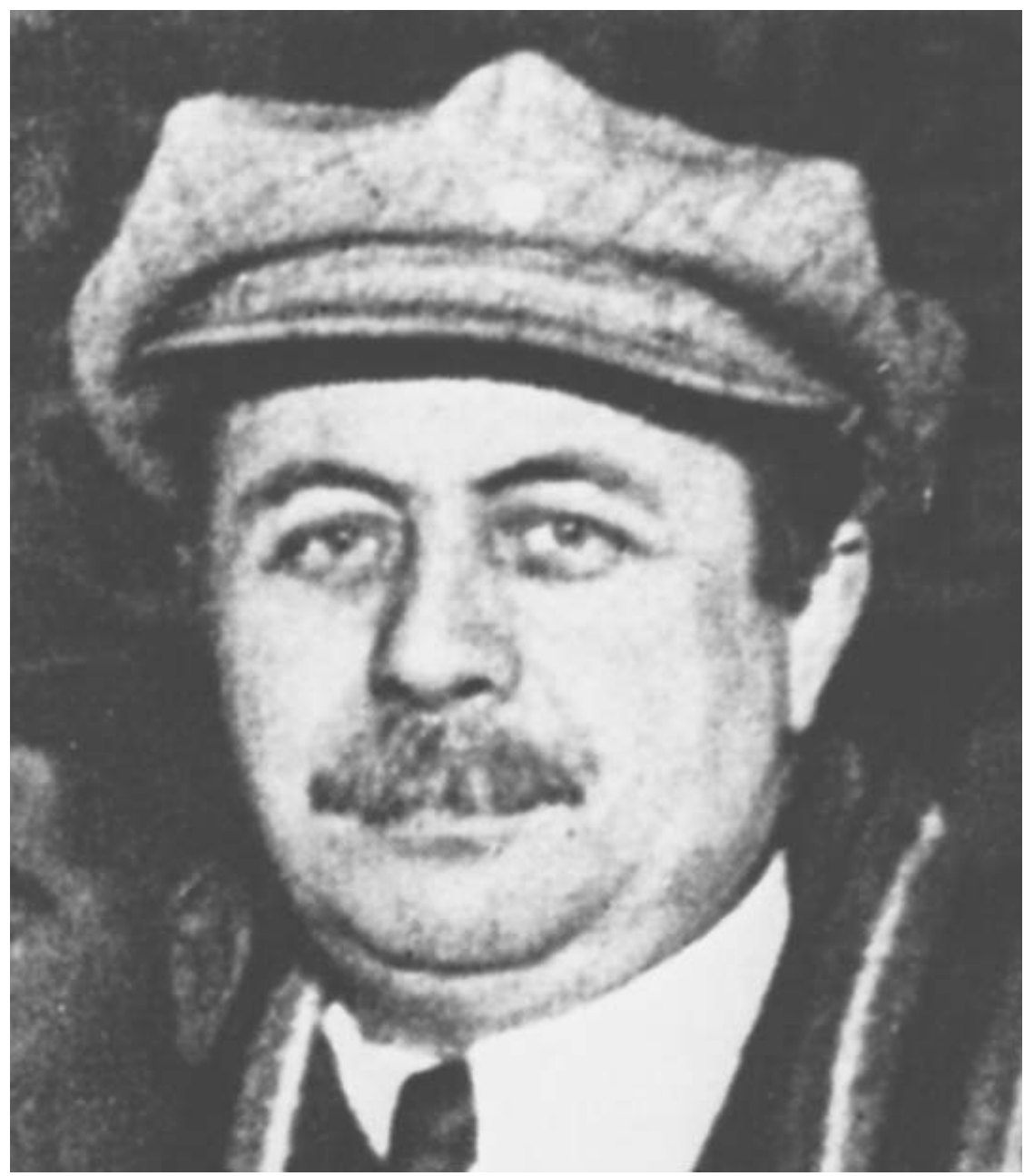

Figure 2. André Marty, date unknown.

Collection IISH, Image and Sound Collection

From September 1935, the impact of André Marty made itself felt on the returning Arnot. As well as his normal duties, he specialized in Trotskyism and the show trials, writing exhaustive analyses on how these matters were being handled in Britain. ${ }^{86} \mathrm{He}$ seems to have chafed against the new order in which CPGB affairs were supervised by a Comintern official, the Polish-born, French-raised ILS graduate, Rosa Michel, who reported directly to Dimitrov. Compared with many of his predecessors, Arnot was

86. R. Page Arnot, Trotskyism on Trial in the Soviet Union, RGASPI, 495/14/209. 
an old hand at processing information and expert in writing reports, while his correspondence is typically detailed. Nevertheless, he was criticized by Marty. ${ }^{87}$ More serious problems, and perhaps an additional clue to his later decline in importance in the CPGB, occurred when he came under the scrutiny of the NKVD over his long-term association with the doomed Petrovsky. ${ }^{88}$

Campbell, also on his second tour of duty, affirmed the reality of the representative's role when he journeyed to London in spring 1939 to quash, with Dimitrov's backing, the CPGB's opposition to conscription. ${ }^{89}$ Springhall's last act, the last act of any British representative, was to travel to Britain the following autumn to correct the CPGB's line on the war in the aftermath of the Hitler-Stalin pact. The decision, taken by Stalin and passed on to Dimitrov, was one in which Springhall had no input. The British representatives to the Comintern had become the Comintern's emissaries to Britain. The idea that Springhall had, in comparison with his recent predecessors, acted like an office boy, neglects qualitative developments in the structure, ideology, and practice of the Comintern apparatus over two decades..$^{\circ}$ To claim that Campbell would, in the end, have acted any differently from Springhall is to misunderstand what the role of the British representative in Moscow had become.

The view that, in the late I930s, specific appointments caused significant friction and exemplified a growing distance between Moscow and London is, on the evidence, an exaggerated one. ${ }^{9 \mathrm{I}}$ While rotation of representatives

87. Marty to Dimitrov, 9 September 1937, RGASPI, 495/74/36. For Marty see Robrieux, Histoire interiéure, p. $40 \mathrm{I}$.

88. William J. Chase, Enemies Within the Gates? The Comintern and the Stalinist Repression, 1934-1939 (New Haven, CT [etc.], 200I), p. 236. Shields may have deputized for Arnot in the summer of 1936: see Arnot to Dimitroff, I6 May 1936, RGASPI, 495/14/220.

89. Thorpe, The British Communist Party, p. 248.

90. Ibid., p. 259, attributes this view to Pollitt; cf. Francis King and George Matthews (eds), About Turn: The Communist Party and the Outbreak of War: The Verbatim Record of the Central Committee Meetings, 1939 (London, 1990), p. 199, where it is clear that the only direct analogy Pollitt made was to compare Springhall with William Strang, a senior civil servant sent to Moscow in 1939 by the Prime Minister, Neville Chamberlain, without full powers to negotiate.

9r. The claim (Thorpe, The British Communist Party, p. 228) that Arnot went back to Moscow "against a degree of Comintern resistance" (our emphasis), is scarcely supported by the sources. They record the party's "offer" of Arnot: "Reply if acceptable". When no reply was received, the CPGB informed Moscow that it had "appointed" Arnot as its representative and Moscow eventually replied: "Secretariat agrees to Arnot as representative". The implication is that "acceptance" and "agreement" were necessary and were given without any "resistance" on the part of the Comintern; Pollitt to CI, 27 December 1935, National Archives, London (NA), HW I7/19, Pollitt to CI, 7, I7 January 1936, Moscow to London, i7 January i936, NA, HW I 7 / 20. Similarly, the bare statement in the minutes "Request for return of Campbell refused. Agreed this is impossible” (PB, 29 June 1939, CPA, CII7), hardly justifies Thorpe's assertion that this constituted "Further evidence of the distance that was opening up between King Street and Moscow"; Thorpe, The British Communist Party, p. 249. Party logistics were plausibly involved 
continued in these years, reappointments ensured that Campbell and Arnot spent considerable time in Moscow, while the tenure of Shields almost twelve months - and McIlhone - one year - contrasted with the more ephemeral roles of Hermon, Kerrigan, and Springhall. Their fates varied. On his return, Rust was appointed Lancashire organizer. After a spell in Spain, he was reinstated as Daily Worker editor in 1939 and continued in the leadership until his death a decade later. In 1943 Springhall was convicted of spying for the Russians. Formally expelled from the CPGB, he lived, after his release from prison, in China and Moscow. Shields's time in Russia and his assiduity was rewarded by further cooption. After editing the Daily Worker, he operated on the Comintern Cadre Commission in the later I930s and remained, until his last illness, a functionary in the CPGB apparatus. Campbell and Kerrigan played a leading open role in the party until 1965. In contrast, Arnot, on his return from Moscow, never recovered his earlier eminence, while McIlhone's ascent in the CPGB was arrested by the end of the I930s. It is therefore difficult to isolate service in Moscow as a significant factor in future progress in the party. Nonetheless, with the possible exception of Hermon, whose trajectory after attending the ILS we have been unable to trace, this cohort remained without exception party members and enthusiasts of the Soviet Union.

\section{THE FRENCH REPRESENTATIVES: A SKETCH}

Allowing for significant differences between the two organizations, a brief examination of the permanent representatives in Moscow of the PCF generates some useful comparisons (see Table 3). The important contextual differences and the superior size and political life of the PCF meant that, in distinction to the CPGB, it maintained a greater variety of representatives of ancillary organizations in Russia in addition to its representatives to the Comintern. Moreover, particularly during the I930s, these representatives had to contend with the presence of ambitious and domineering senior party figures such as André Marty and Jacques Duclos, who were pursuing careers in the Comintern apparatus in Moscow $^{92}$ (see Table 4, p. 233).

Table 3 sets out basic details of fifteen representatives of the PCF from

and the matter was to be reviewed by the British in three months time. Writing to the Comintern the previous year, Pollitt had not only emphasized the importance of Campbell to the CPGB but also commented: "I want to mention Comrade Campbell's health [...]. It is impossible for him to do much walking or standing because of the accident to both his feet"; Pollitt to Piatnitsky, 6 May I938, RGASPI, 495/74/37. This may have been a factor in the decision.

92. For Marty, see above pp. 227-228. For Duclos, see Gotovitch and Narinski, Komintern, pp. 259-269. 


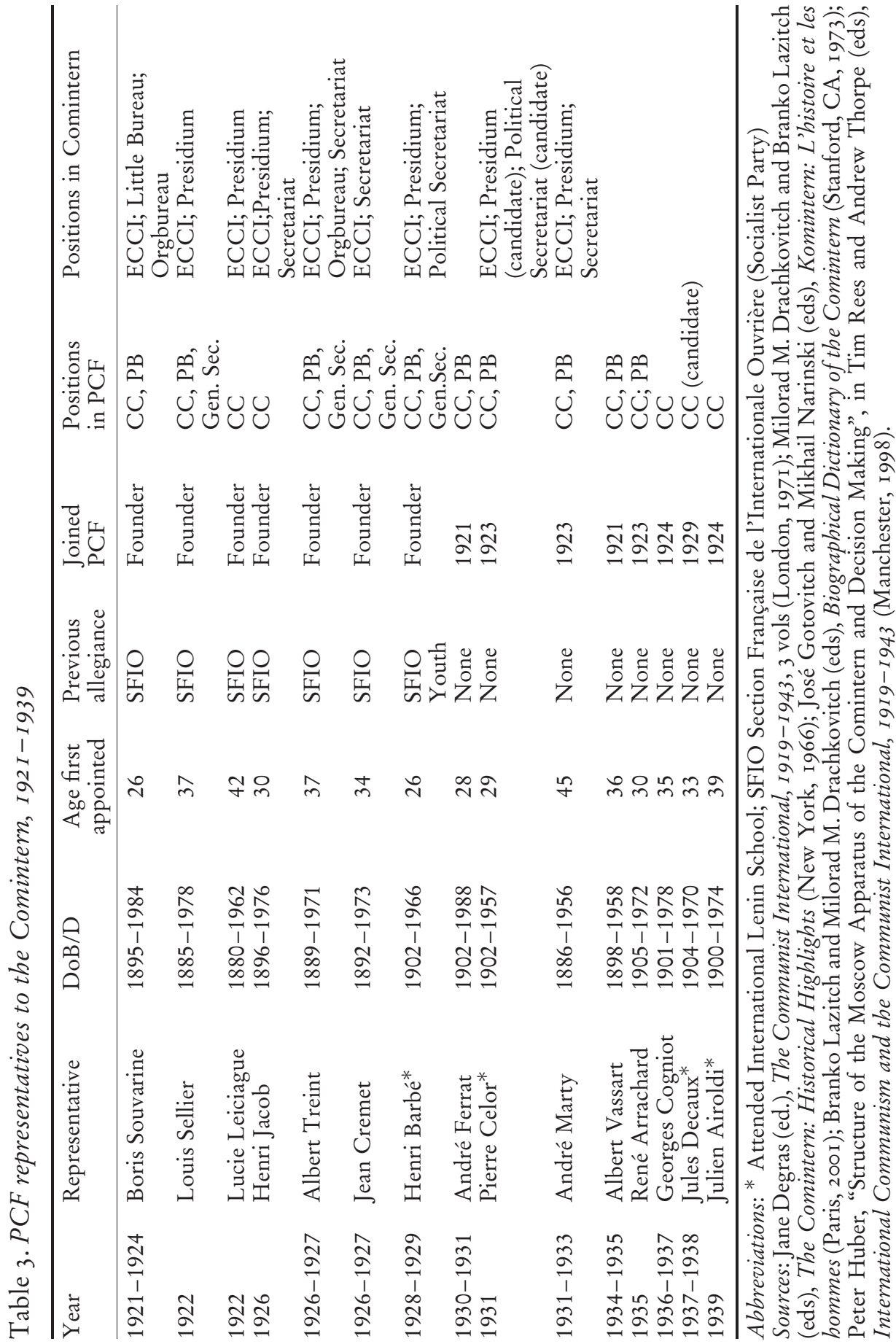


I92 I to $1939 .{ }^{93}$ There is little difference in the average ages of the two groups. That of the French was thirty-four on appointment, compared with thirty-seven for the British (excluding Petrovsky). As in the British case, the appointment rotated and was often of very short duration. Louis Sellier served for a few weeks; Lucie Leiciague, Jean Cremet, and Pierre Celor, for a few months; Albert Treint only a little longer; and André Ferrat, René Arrachard, and Julien Airoldi some six months; Jules Decaux and Albert Vassart served a year; Henri Jacob a little more, but as was certainly the case with longer serving members such as Boris Souvarine, Henri Barbé, and Marty, their stay in Moscow was interrupted by periodic trips to attend to Comintern business elsewhere or to the affairs of the PCF. Georges Cogniot, for example, combined intensive work in Moscow with membership of the Chamber of Deputies and leadership of the Teachers' International in France. Unlike some of their British counterparts, the French were rarely confined to Moscow. ${ }^{94}$

In social origin, the French cohort, like the British, was almost completely proletarian - even its petit-bourgeois component was marginal: Celor's father was a barber, Souvarine's a self-employed, immigrant jeweller - a fact which bespeaks the social spine of the cadre of west European communism. Judged by their initial destinations, however, the French group was somewhat less working-class than the British. Treint and Cogniot were teachers - the latter attended the École Normale Superieure. There is some evidence that Ferrat attended college, while Celor, starting in the railway workshops, became a manager and bookkeeper. As with the British contingent, skilled workers were conspicuous. Marty was a naval engineer, Barbé and Airoldi were metalworkers, Vassart was an iron moulder, Decaux, a boilermaker; Jacob was a hatter, Sellier, a Paris postman.

Moreover, the five representatives during the Lenin and Zinoviev periods possessed, like their British contemporaries, significant experience in pre-PCF politics and were founder members who eventually became senior figures in the party. Their eminence was as great, if anything greater, than that of their British counterparts. Souvarine was, in the early I920s, perhaps the major force in the party, and three representatives, Sellier, Treint, and Cremet were secretaries of the PCF. However, it is

93. This section draws on Lazitch, "Two Instruments of Control”, Lazitch and Drachkovitch, Biographical Dictionary, and the recent and fuller Gotovitch and Narinski, Komintern, which is extensively based on Comintern files. Some authorities, for example, Kriegel, French Communists, p. 274, include François Billoux (1903-1978) in the list of permanent representatives. Although he represented the Communist Youth on the KIM (Communist International of Youth) in 1928, Gotovitch and Narinski, Komintern, pp. I59-163, do not designate him as a representative of the party and we have followed them here. The inclusion of Cremet is also debateable but see ibid., p. $55 \mathrm{I}$.

94. Ibid., pp. 21 5-216. 


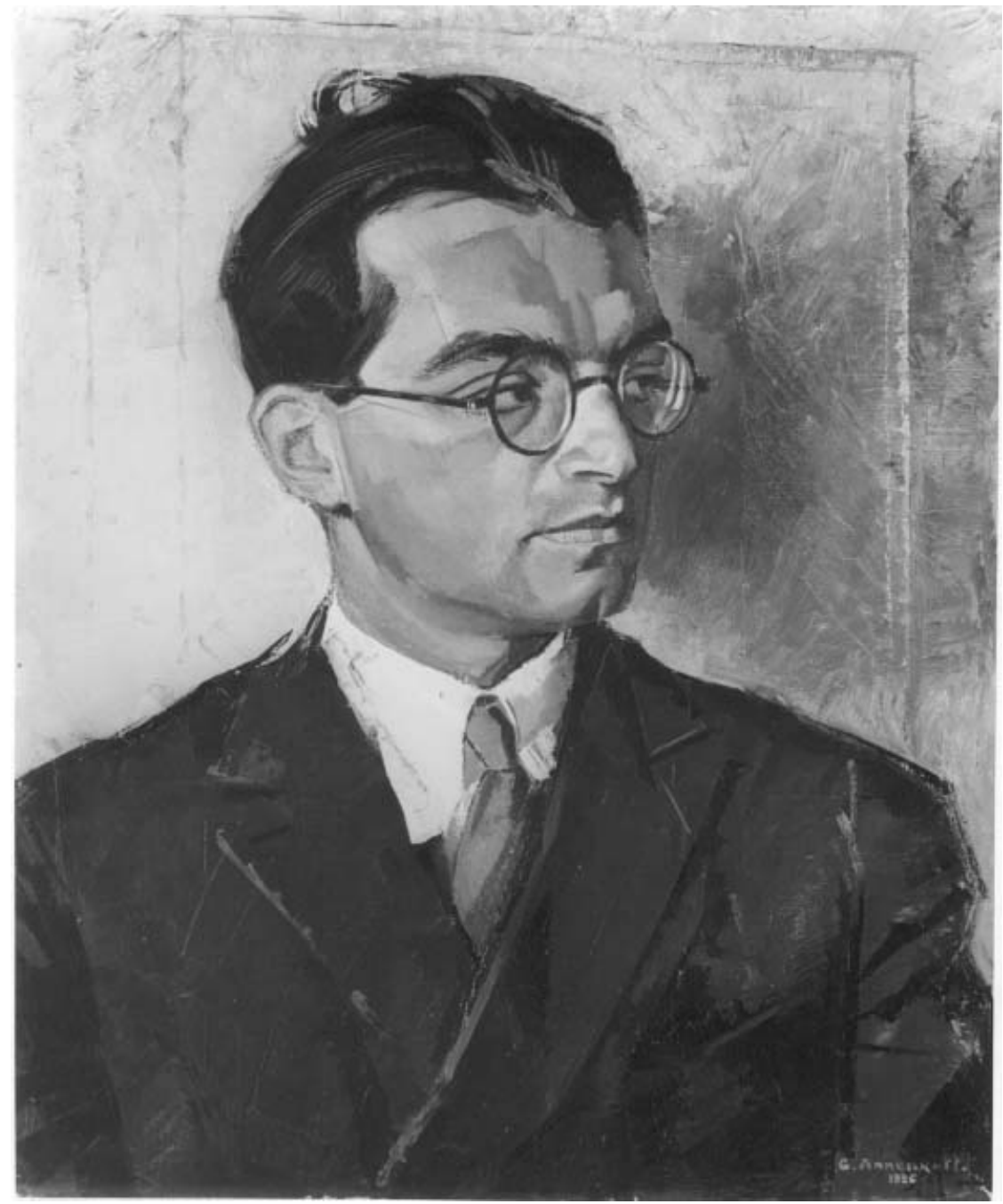

Figure 3. Boris Souvarine portrayed by Georges Annenkov, I925.

Collection IISH, Image and Sound Collection

noteworthy, in terms of career progression, that while Sellier became secretary after his appointment to the Comintern, Treint and Cremet were sent to Moscow after they had held this office in the PCF, and in the former's case, an element of political correction was involved in his relocation in Russia. ${ }^{95}$

95. Cf. Wolikow, "L’Internationale communiste", p. 84. 


\section{Table 4. French communists on the ECCI and its committees}

\begin{tabular}{|c|c|c|}
\hline 1920 & 2nd Congress & Alfred Rosmer \\
\hline 1921 & Before 3rd Congress & Rosmer (Little Bureau) \\
\hline 1921 & 3rd Congress & Boris Souvarine \\
\hline 1921 & After 3rd Congress & $\begin{array}{l}\text { Souvarine (Little Bureau); [Paul Vaillant-Couturier, } \\
\text { International Control Commission, Antione Keim, } \\
\text { deputy] }\end{array}$ \\
\hline 1922 & 1st Plenum & Souvarine (Presidium), Louis Sellier (Presidium) \\
\hline 1922 & 2nd Plenum & Souvarine (Presidium), Lucie Leiciague (Presidium) \\
\hline 1922 & 4th Congress & $\begin{array}{l}\text { Souvarine (Presidium), Ludvic Oscar Frossard, Jean } \\
\text { Duret (candidate), Georges Lévy (candidate, } \\
\text { Presidium) }\end{array}$ \\
\hline 1923 & 3rd Plenum & Souvarine (Presidium, Orgbureau) \\
\hline 1924 & 5th Congress & $\begin{array}{l}\text { Sellier, Albert Treint, Pierre Semard, Jacques Doriot } \\
\text { (candidate), Suzanne Girault (candidate), Guy Jerram } \\
\text { (candidate); [Marcel Cachin, ICC] }\end{array}$ \\
\hline 1924 & 4th Plenum & $\begin{array}{l}\text { Semard (Presidium), Treint (candidate, Presidium; } \\
\text { Secretariat; Orgbureau) }\end{array}$ \\
\hline 1925 & 5th Plenum & Treint (Orgbureau) \\
\hline 1926 & 6th Plenum & $\begin{array}{l}\text { Semard, Treint (Orgbureau), Henri Jacob } \\
\text { (Secretariat) }\end{array}$ \\
\hline 1926 & 7th Plenum & $\begin{array}{l}\text { Semard (Presidium), Jean Cremet (Presidium, } \\
\text { Political Secretariat); Treint (candidate, Presidium) }\end{array}$ \\
\hline 1927 & 8th Plenum & $\begin{array}{l}\text { Alfred Bernard (Presidium), Semard (Presidium), } \\
\text { Treint (candidate, Presidium), Henri Barbé (Political } \\
\text { Secretariat) }\end{array}$ \\
\hline 1928 & 9th Plenum & Barbé (Presidium), Semard (Presidium) \\
\hline 1928 & 6th Congress & $\begin{array}{l}\text { Barbé (Presidium, Political Secretariat), Semard } \\
\text { (Presidium), Maurice Thorez, Doriot (candidate), } \\
\text { Benoit Frachon (candidate), Gaston Monmousseau } \\
\text { (candidate), François Billoux (candidate for the YCI); } \\
\text { [Cachin, ICC] }\end{array}$ \\
\hline 1929 & 10th Plenum & $\begin{array}{l}\text { Barbé (Presidium, Political Secretariat), Semard } \\
\text { (Presidium) }\end{array}$ \\
\hline 1931 & 11th Plenum & $\begin{array}{l}\text { Barbé (Presidium), Cachin (Presidium), Thorez } \\
\text { (Presidium, Political Secretariat), Pierre Celor } \\
\text { (candidate, Presidium, candidate, Political Secretariat) }\end{array}$ \\
\hline 1932 & 12th Plenum & $\begin{array}{l}\text { Cachin (Presidium), Thorez (Presidium, Political } \\
\text { Secretariat) }\end{array}$ \\
\hline 1933 & 13th Plenum & $\begin{array}{l}\text { Cachin (Presidium), Thorez (Presidium, Political } \\
\text { Secretariat) }\end{array}$ \\
\hline 1935 & 7th Congress & $\begin{array}{l}\text { Cachin (Presidium), Jacques Duclos, André Marty } \\
\text { (Presidium, Secretariat), Thorez (Presidium), } \\
\text { Raymond Guyot (candidate, Presidium, for YCI), } \\
\text { Frachon (candidate); [Monmousseau, ICC] }\end{array}$ \\
\hline
\end{tabular}

Note: Names in italics indicate PCF representatives to the Comintern at some point during this period.

Sources: Vilém Kahan, "The Communist International, I919-43: The Personnel of Its Highest Bodies”, International Review of Social History, 2 I (I976), pp. I 5 I- I 8 5; Jane Degras (ed.), The Communist International, 1919-1943, 3 vols (London, I971); José Gotovitch and Mikhail Narinski (eds), Komintern: L'histoire et les hommes (Paris, 200I); Branko Lazitch and Milorad M. Drachkovitch (eds), Biographical Dictionary of the Comintern (Stanford, CA II I z $)$. 
It is the differences between the two cohorts which take the eye. Males were almost exclusively dominant in the leadership of both parties and no woman appears among the British group. In contrast Leiciague, the determined daughter of a carpenter in the Basses-Pyrénées who became a shorthand typist, experienced a swift rise in the PCF, as well as playing an admittedly brief role in its international alignments. ${ }^{96}$ Moreover, with the PCF, the tendency to appoint top leaders was more sustained than was the case with the CPGB, while Table 4 suggests that they took a slightly stronger role in the formal representative machinery of the Comintern. After 1926, Cremet, Barbé, Celor, and Marty possessed more elevated standing in their party than their British equivalents. Moreover, the mysterious Cremet, who after 1927 travelled the world as a Comintern agent, and the charismatic if impulsive, unpredictable, and temperamental Marty, son of a Communard, hero of the Black Sea mutiny and a former freemason, rose to a prominence in the apparatus never achieved by a British figure. ${ }^{97}$

After I935, however, there is some convergence between the two groups. The submission of both parties to Stalinism is reflected in the selection of younger, more junior cadres who were members of the Stalin generation: Arrachard, Cogniot, Decaux, and Airoldi, all born in the twentieth century, all with minimal political experience outside the PCF. However, the persistence in the British group at the end of the I930s of the older Stalinists, Arnot and Campbell, is worth noting. Two of the PCF's last four representatives and two of the CPGB's last four representatives were graduates of the Stalinist Academy, the ILS - overall, four British and four French representatives attended the school.

Yet the sense of difference persists. The CPGB never produced a largerthan-life rebel anywhere near the stature of Souvarine. His turbulent career before 1927 suggests the relative openness of the early years of the Comintern, its restriction after 1924 under Zinoviev, and its closure from I 929 under Stalin's nominees, Molotov and Dimitrov. Initially the Kievborn Souvarine was able to use his position in Moscow - where he mixed on equal terms with Trotsky, Zinoviev, and Stalin, as well as the international communist community - and his support for the Comintern to shore up the embattled left wing in the PCF. It is difficult to conceive in the British case of a second representative being appointed - as Sellier was to represent the PCF centre - to give formal voice to a faction in the party.

However, Souvarine's disillusion with the troika of Zinoviev, Kamenev, and Stalin, and his opposition to the growing assault on Trotsky, meant he was pushed into using his base in the PCF left to oppose the Comintern.

96. Gotovitch and Narinski, Komintern, p. 388.

97. For Cremet's later career see Roger Faligot and Rémi Kaufer, As-Tu Vu Cremet? (Paris, I991). For Marty, see Robrieux, Histoire interiéure, p. 40I. 
His support for the opposition at the Thirteenth Congress of the Russian party in May 1924 prefaced his expulsion from the PCF at the Fifth Comintern Congress that summer. Souvarine's independence, ability to think for himself, and opposition to the bureaucratization of Soviet Russia and the Comintern stand in contrast to the routine orthodoxy of the former apostles of rank-and-file insurgency in Scotland, Bell, MacManus, and Gallacher. The contrast between the British and French representatives at this time is suggested by Murphy's condemnation of Souvarine at the ECCI Plenum in December $1926 . .^{8}$

Oppositional tendencies persisted within the PCF. Treint, a prominent supporter of the troika and leader of the PCF delegation to the Fifth Comintern Congress, played a part in Souvarine's downfall. But, as Stalin and Bukharin came to the fore, a similar fate awaited the former army captain. Despatched to Moscow after his demotion in the PCF, he found himself under attack in Bolshevik and Pravda, the subject of what he termed "a veritable pogrom" directed against the ornaments of Zinoviev's Comintern. His attempt to save himself by signing a statement calling for Zinoviev's resignation was unsuccessful, and after severe criticism at the Seventh Plenum in November 1926, he was sent home in February 1927. Expelled from the party in January 1928, he was later a supporter of the French Trotskyists (in I93 I-I932) before returning to his original political home in the SFIO (Section Française de l'Internationale Ouvrière) in I 934. Sellier survived until the end of the decade, breaking with the PCF in December 1929 and leading the Parti Ouvrière Paysan and Parti d'Unité Prolétarienne before his reconciliation with the SFIO. 99

It is remarkable that of its fifteen representatives in Moscow, no less than ten were expelled, or broke with the PCF, during the years of the Comintern. In addition, Marty was expelled in I953. The only survivors were les fidèles fils de Staline, Arrachard, Cogniot, Decaux, and Airoldi. Even here, Cogniot's youthful opposition to "Bolshevization" must be noted. Moreover, in the majority of cases the breach was political: Cremet's disappearance from communist politics remains unexplained, but in the other instances the reasons for rupture centred on opposition to the line. ${ }^{100}$

After Souvarine, the most notorious casualties were Barbé and Celor,

98. Boris Souvarine, À Contre-Courant, Écrits, $1925-1939$ (Paris, 1985); idem, What Became of the Revolution? Selected Writings of Boris Souvarine (London, 200I); Robrieux, Histoire interiéure, pp. 192-218. For the atmosphere of the time, see Alfred Rosmer, Lenin's Moscow (London, I97I). The brief despatch of Gallacher to Moscow by the CPGB in 1927 to work with Murphy may be perceived as a parallel with the Souvarine-Sellier situation. But it was a pallid one, for Gallacher's presence was essentially a fig leaf to cover Comintern insistence that Murphy represent the CPGB.

99. Lazitch and Drachkovitch, Biographical Dictionary, pp. 410-4I I, 361-362.

I00. See note 93 above. 
the youth leaders sponsored by Moscow to lead the PCF during the Stalinization of the Third Period, who were denounced at the Presidium of the Comintern in October I93 I as agents of the Mensheviks and confederates of the Russian opposition group led by Lominadze. After elaborate investigations in Moscow and Paris, directed by Manuilsky and involving Marty, Ferrat, and Vassart, Celor was branded a police agent. Negotiating difficulties in getting out of Russia, he was expelled from the PCF in 1932. He was only briefly survived by Barbé, who was relieved of his offices in I93 I, and expelled in I934 on the basis of his links with the mercurial mayor of Saint-Denis, Jacques Doriot. Both Barbé and Celor were later prominent in Doriot's Parti Populaire Français, of which Barbé was general secretary, and Marcel Deat's Rassemblement National Populaire, serving prison sentences for collaboration in the postwar years. ${ }^{101}$

Less spectacularly, Leiciague left the PCF because of Stalin's treatment of the leaders of the Russian opposition in 1929. As a union leader, Jacob never really stomached "class against class"; he broke with the party in 1932. Ferrat, too, developed differences over the Third Period and animated the opposition group, which from 1932 published the journal Que Faire? Refusing a summons to Moscow in I 936, he was removed from the PB and then the CC and finally expelled. Like Leiciague and so many others, he returned to the SFIO. Vassart had flirted with Doriot over opposition to the Third Period. But he recanted, and when he finally left the party it was in opposition to the line on the war which flowed from the Hitler-Stalin pact. ${ }^{102}$ Cogniot and Decaux featured in the PCF leadership until the I960s but Airoldi and Arrachard did not. As in the British case, service as a representative was far from a passport to future success in the party; indeed, for the French, at least statistically, it was a prelude to leaving it.

If the French were unarguably more politically independent and decidedly more colourful than their counterparts in the CPGB, the Stalinization dramatically incarnated in the Barbé-Celor episode ensured that by the early I930s their representatives suffered a similar subordination. In contrast to the British contingent after the early years, the French representatives have left brief testimony as to their role under Stalinism. At the start of the I930s, Ferrat recollected that, unlike Souvarine, he enjoyed no access to the Soviet leadership, indeed he had limited contact with even the lower echelons of the Russian party. Power was concentrated at the

ıог. Pierre Broué, Histoire de l'Internationale communiste, 1919-43 (Paris, 1997), p. 497; Courtois and Lazar, Histoire du Parti communiste, pp. 104-105; Robrieux, Histoire interiéure, pp. 366-376 (on Celor), pp. 380-38 I (on Barbé). See also Maurice Thorez, Fils du Peuple (Paris, 1949), p. 69 .

I02. Broué, Histoire de l'Internationale, pp. 996, I099; Gotovitch and Narinski, Komintern, pp. 388,28 I $-283,568-570$. 
apex where the Comintern met the Stalinist state, in the political secretariat whose members were Manuilsky, Piatnitsky, Kuusinen, the Italian Palmiro Togliatti, and the German Wilhelm Pieck. ${ }^{103}$

Ferrat worked from $8 \mathrm{am}$ to $5 \mathrm{pm}$ in the Latin secretariat, headed by Souvarine's old antagonist, the Russian Ivan Stepanov, advised by the future Romanian minister Anna Pauker, and Varia Labeda, an auxiliary of the NKVD. The secretariat included representatives of the Italian and Swiss parties, but Ferrat depicts his own functions, even as an information resource, as restricted. The Comintern was also able to draw directly on the PCF leadership, the ECCI delegate to France, the Czech Eugen Fried, who was closely linked to Pauker, the Soviet embassy, and the NKVD in Paris, as well as the contacts Stepanov had cultivated on his own visits to France. Ferrat was not even informed of the diverse traffic between Comintern headquarters and its information sources in France. His contact with the PCF leadership was restricted and under surveillance, for communications went first to Stepanov and then to Manuilsky and Piatnitsky. Ferrat was consulted over the financial subsidies to the PCF. But it was clear that by I93 I the representative's role was being strategically controlled, deskilled, integrated into the apparatus, and bureaucratized. ${ }^{104}$

By the end of Vassart's stay in Moscow in 1934-1935, matters were formalized. He emphasized that the Comintern leadership took all decisions on the political line. These could not be questioned: discussion was confined to application and execution of predetermined policy. Vassart affirmed that the move from the Third Period to the Popular Front was decided by the Russians on the basis of considerations of foreign policy, but that he played a part in providing information on the situation in France to the Russians and, conversely, persuading the PCF of the validity of the new line. Vassart's appointment was announced by Maurice Thorez on his return from Moscow: only then was his consent elicited. He was an experienced activist who had been involved in the cadre department and the secret apparatus of the PCF. Yet the meat of his discussions with Manuilsky was informal, although "he was expected to help change the tactics of the French Communist Party [...] [he] did not once see Stalin or any other leader of the Soviet Communist Party". ${ }^{\text {Ios }}$ However, he was employed to draw up policy documents to be sent to the PCF in the light of the developing Stalinist line, and claimed to have influenced the Comintern's abortive summons to the recalcitrant Doriot to come to Moscow.

103. Lazitch, “Two Instruments of Control”, pp. 59-6r.

I04. Ibid. For Fried, see Annie Kriegel and Stephane Courtois, Eugen Fried: Le grand secret du PCF (Paris, 1997).

I05. Vassart and Vassart, "Popular Front", pp. 243, 246. 
The peremptory, power-laden flavour of transactions is conveyed by his vivid recollection of a meeting where Fried asked Manuilsky:

"What is the main thing required of me?"

"Do you think that a Comintern delegate should ask such a question? You will return to Paris."

Vassart took up Fried's defence.

Manuilsky asked him to be quiet. "You are not qualified to talk about it", said

Manuilsky. "We know our own personnel better than you do."

"Personnel? He is the Executive delegate!" ${ }^{106}$

By I935, designations such as "delegate" and "Comintern executive" had been drained of the real content they had possessed in 1920. The Comintern now dealt in "personnel", and its staff were expected to know their place. Under the nomenclature, the permanent representatives of the PCF, like those of the CPGB, had become cogs in the hierarchical Comintern machinery, itself an ancillary component of the Russian state. Decaux was typical of the contemporary representatives of a party formally second in importance to the Russian party: "a second echelon party worker $[. .$.$] who had never carried any weight in Moscow or, for that$ matter, in Paris". ${ }^{107}$

\section{CONCLUSION}

The British representatives to the Comintern had six functions. First, they represented the views of their party to the Comintern and the views of the Comintern to their party. Second, they acted as a link, providing information on what was happening in Britain and in the CPGB to Moscow, and information on what was happening in the Comintern and Russian party to London. Third, they alerted both their party and the Comintern to future developments. Fourth, they supplemented the role of the Comintern hierarchy by explaining and monitoring instructions and advice. Fifth, they acted to stimulate the flow of finance from Moscow to London. Sixth, they acted to supervise and, if necessary, succour British communists in Russia.

Service in Moscow may have given representatives a short-term advantage over their competitors for leadership positions, although even this is difficult to establish. In the longer term there is little evidence that a spell in Moscow beneficially facilitated future career advancement. This is borne out by our comparisons with the representatives of the French party. However, in relation to the PCF, the role is, in contrast with the CPGB, negatively related to maintenance of party membership and allegiance to Soviet Russia. In the early years the activities of the British

107. Lazitch, "Two Instruments of Control”, pp. 63-4. 
representatives were relatively unconstrained. However, their role was increasingly formalized; it was significantly different in the 1930s, and particularly after 1935, than it had been in the early and even the midI920s. After 1935 the Kerrigans, Arnots, Campbells and Springhalls were substantially:

[...] small bureaucrats who had to execute the duties they were employed for. Attached to a specific secretary of the Comintern they served as his auxiliaries. Their working conditions were prescribed in detail and they were subjected to strict control; their entire correspondence, for instance, had to pass through the hands of their superior. Their main task was to keep him informed on their party. ${ }^{108}$

Thus the British representatives were increasingly coopted by the Comintern, whose functionaries they became. They were not ambassadors or consuls - or negotiators. They did not operate from or develop an independent base, deploy independent power, or take or influence decisions of any political significance. They were increasingly subordinate within both the Comintern, on whose behalf they came primarily to operate, and within the CPGB. When tensions emerged, and there were few, they were resolved in favour of Moscow. By the end of the period, the British representatives were integrated into the Comintern apparatus as an information resource and a communication channel for Russian thinking. But at no point, even in the I920s, is there any evidence that any of them shaped Comintern policy. Rather, comparison with the French group highlights their conformity with policy shaped by the Russian leadership.

Our study goes some way to confirm our initial hypothesis: coming from a more rooted, powerful party, whose politics meant more at home and whose culture catered for a degree of heterodoxy and disputation, the Gallic cohort exercised more independence. But certainly after the Lenin years, it is impossible to conclude that the French representatives possessed any substantial purchase on Comintern policy, still less "negotiated" it - at least in any meaningful bargaining sense of that term. What is remarkable is the emerging unequal structure and outcome of political exchange. What represents the triumph of ideology and "internationalism" is the increasing subordination of the leaders of this powerful, anchored, national, political community, to Moscow. With the CPGB matters were even more so: a marginal party exercised marginal influence. However, Stalinism took its toll on all Comintern affiliates: by the mid-r93os the role of the French representative was similar to that of the British. ${ }^{109}$ 
There were no British Souvarines, no Tascas (as in the Italian party), no Vuyovitchs (as in the Yugoslav party). ${ }^{\text {Iо }}$ Even Murphy, who played a prominent role, acted against such heretics and executed, to the best of his ability, the policy of the ruling faction in Russia. With the possible exceptions of Arnot and Campbell, they were not politicians, still less political thinkers of even the second rank. Their first and essential attribute was a disciplined orthodoxy. Set next to the French representatives, this manifest conformity affirms that Russian hegemony worked more quietly but more effectively in London than in Paris. But it worked in Paris too. A Vassart was consulted; he was listened to. His views might be integrated into strategy. But by others - policy-making was beyond his reach.

If this was so for the PCF, it was certainly more so for the CPGB. The only evidence Andrew Thorpe adduces for his assertion that CPGB representatives "could play a significant role" in influencing policy is that the mediocre McIlhone, who lacked Vassart's record, "seem[ed] to have had a major hand in presenting Pollitt's view that the party line must be

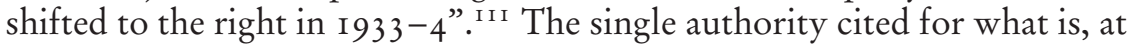
best, a conflation of presentation with power, is a letter from the CPGB's Clemens Dutt in Moscow to his brother Rajani Palme Dutt. Clemens claims that, at a party, "Bob" [McIlhone] had told him that he [Rajani] had written an article "which was right off the line", and that he had heard indirectly that McIlhone was claiming Dutt's book on fascism "contains very bad left deviations". "I2 Questionable inferences based on tangential gossip in mid-November 1934, when the shift in line away from the Third Period had already been agreed by Stalin and Dimitrov and preparations for the Seventh Congress were in train, scarcely constitutes persuasive evidence that either Pollitt or Mcllhone played a significant role in the process. ${ }^{113}$ On any proper assessment, the British representatives in Moscow were not plenipotentiaries of the CPGB but rather served the bureaucratic power of the rulers of Russia.

from the Comintern's leadership were taken at the VKP Plenums"; Fridrikh Firsov, quoted in McDermott and Agnew, Comintern, p. 44.

I Iо. For Tasca's defiance and assault on Togliatti, see Paolo Spriano, Storia del Partito Communista Italiano, vol. 2 (Turin, 1969), pp. 505-508. For Vuyovitch's opposition and his execution by Stalin, see Broué, Histoire de l'Internationale, p. I 102, and Michal Reiman, The Birth of Stalinism: The USSR on the Eve of the "Second Revolution" (London, 1987), p. 3 I. i I I. Thorpe, "Comintern Control", p. 646.

I I 2. Clemens Dutt to Rajani Palme Dutt, i 8 November 1934, CPA, CP/IND/DUTT/03/07. I I 3. Alexander Dallin and Fridrikh Firsov (eds), Dimitrov and Stalin, 1934-1943: Letters from the Soviet Archives (New Haven, CT [etc.], 2000), pp. 10-16. 